\title{
A CAÇA E SEUS EFEITOS SOBRE A OCORRÊNCIA DE MAMÍFEROS DE MÉDIO E GRANDE PORTE EM ÁREAS PRESERVADAS DE MATA ATLÂNTICA NA SERRA DE PARANAPIACABA (SP)
}

\author{
CAMILA CAMARA PIANCA
}

Dissertação apresentada à Escola Superior de Agricultura "Luiz de Queiroz", Universidade de São Paulo, para obtenção do título de Mestre em Ecologia de Agroecossistemas.

P I R A C I C A B A

Estado de São Paulo - Brasil

Dezembro - 2004 


\section{A CAÇA E SEUS EFEITOS SOBRE A OCORRÊNCIA DE MAMÍFEROS DE MÉDIO E GRANDE PORTE EM ÁREAS PRESERVADAS DE MATA ATLÂNTICA NA SERRA DE PARANAPIACABA (SP)}

\section{CAMILA CAMARA PIANCA}

Bióloga

P I R A C I C A B A

Estado de São Paulo - Brasil

Dezembro - 2004 


\section{Dados Internacionais de Catalogação na Publicação (CIP) DIVISÃO DE BIBLIOTECA E DOCUMENTAÇÃO - ESALQ/USP}

\section{Pianca, Camila Camara}

A caça e seus efeitos sobre a ocorrência de mamíferos de médio e grande porte em áreas preservadas de Mata Atlântica na Serra de Paranapiacaba (SP) / Camila Camara Pianca. - - Piracicaba, 2004

$$
74 \text { p. : il. }
$$

Dissertação (Mestrado) - - Escola Superior de Agricultura Luiz de Queiroz, 2004.

Bibliografia.

1. Caça 2. Conservação biológica 3. Fiscalização 4. Legislação ambiental 5. Mamíferos 6. Mata Atlântica 7. Ocorrência 8. Proteção ambiental I. Título

CDD 591.5

\section{"Permitida a cópia total ou parcial deste documento, desde que citada a fonte - O autor"}


Dedico:

aos meus queridos pais, Rosa Maria e Antonio Carlos pelos ensinamentos da vida, apoio e incentivo nesta minha jornada e por compartilhar comigo um profundo amor e respeito pela natureza.

Em memória à Luiz Fogaça Balboni (Zižo) pelo seu ideal de vida. 


\section{AGRADECIMENTOS}

À minha orientadora pelo apoio, elogios e principalmente confiança no meu trabalho.

Ao meu grande mestre e amigo Paulo Inácio K. L. Prado pela oportunidade de compartilhar e vivenciar valiosos ensinamentos, com sua paciência e entusiasmo confortadores. Obrigada pelo apoio, confiança e amizade, imprescindíveis para a concretização desta dissertação.

À Renata Pardini pela amizade e colaboração no delineamento experimental e análise de dados que foram fundamentais no trabalho.

À Luciano Martins Verdade pelo apoio e sugestões valiosas na dissertação.

À Beatriz de Melle Beiseigel (Bia) pela amizade e ajuda na escolha e reconhecimento da área da Sede (PECB), além das valiosas sugestões para a dissertação.

À Alexandre Bastos pela amizade, apoio no trabalho de campo, produção dos mapas e análises estatísticas, enfim por compartilhar comigo sua experiência e inteligência.

Ao Diretor do PECB, José Luiz Camargo Maia pela amizade, apoio e confiança no meu trabalho. Agradeço também pelo seu empenho e coragem na luta pela preservação da natureza e no apoio às comunidades tradicionais da região.

À equipe do Parque do Zizo, em especial aos amigos Francisco Balboni Fogaça (Chico) e seu jipe, o único que não nos deixava na mão, e Jorginho (JJJorge!!) pela amizade, carinho, apoio e valiosas informações sobre a região, fundamentais para realização deste trabalho. Enfim, "sei lá” por tudo!

Aos estagiários de biologia e engenharia ambiental, Guilherme e Patrícia (PUC-SP), Rodrigo (UNESP), Ana, André, Anselmo, David, Fernando, Marcelo, Oswaldo, Priscila, Rafael, Samira e Willian (Faculdade Oswaldo Cruz), pela amizade e apoio no trabalho de campo. 
À Carlos Eduardo Marinelli (Caê) pela amizade, carinho e valiosas sugestões e também por confiar seus alunos nos projetos que auxiliaram nas questões desta dissertação.

À Rômulo Fernandes Batista pela amizade e ajuda na elaboração dos mapas das áreas. Aos amigos "carregadores de areia" Raul (CCCheiro!!!), Fernando (Negão), Rafa, Rodrigo (Batoré), Ricardo (Santo), Alan (Japonês), Douglas e seu cunhado (Abaitinga) pela amizade e ajuda nesta tarefa tão árdua, me perdoem pela dor nas costas...eu tentei compensar com piadinhas e cervejas no final do dia.

À família Fogaça (Fogaçinha, Issira, Paula, Gui e Henrique) pela amizade e pela carinhosa hospedagem por tantas vezes na cidade de São Miguel Arcanjo.

À minha amiga e companheira de campo Paula Daniel Fogaça (Paulinha) pela participação integral e ajuda em todas as etapas deste trabalho e por tantos momentos de aventura na selva que passamos juntas.

Em especial ao meu grande amigo Elias Brás (Seu Elias) pelo carinho, amizade e pela companhia nos dez meses que morei no sítio Recanto do Sertão e principalmente pelos preciosos ensinamentos sobre a região, os animais, as árvores e sobre a vida no sertão.

Ao amigo Fabinho pelo carinho, paciência e apoio em tudo que eu faço.

Aos companheiros da Reserva Brasil Cristiano Trapé Trinca (Cris), Carlos Eduardo Marinelli (Caê), Carla Ferreira Josef (Cá), Nelson Calil Filho (Nelsão) e Rômulo Fernandes Batista pelo apoio e infinitas discussões que foram essenciais para minha formação pessoal e profissional. Em especial a minha amiga e companheira no curso de mestrado Francesca B. L. Palmeira (Thesca) pelo apoio e que mesmo diante de tantas dificuldades, saímos vitoriosas com sucesso de nossos projetos.

Às minhas avós, Fíca e Cida e meus irmãos Luiz Gustavo e Carolina pelo apoio e incentivo sempre. A toda minha família, em especial ao tio Vanderlei, e amigos por serem compreensivos e atenciosos em todos os momentos desta etapa da minha vida.

Ao Instituto Florestal (IF - COTEC) pela rapidez na liberação da autorização de pesquisa e apoio logístico no PECB.

À Reserva Brasil e DPZ pelo apoio a pesquisa.

Ao Sr. Florentino Carlos Godoy (Yorker) pelo financiamento concedido a esta pesquisa. 


\section{SUMÁRIO}

\section{Página}

LISTA DE FIGURAS........................................................................ ix

LISTA DE TABELAS......................................................................... $\quad$ xi

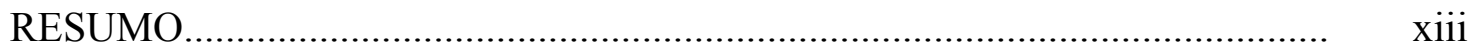

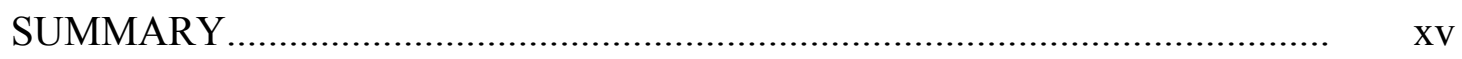

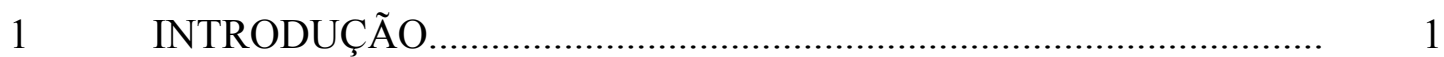

$1.1 \quad \mathrm{O}$ efeito da caça sobre as populações animais....................................... 3

1.2 Legislação brasileira e fiscalização dos recursos naturais..................... 5

$2 \quad$ MATERIAL E MÉTODOS.............................................................. 7

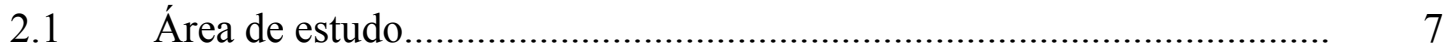

2.1.1 Parque Estadual Carlos Botelho......................................................... 7

2.1.2 Reserva Particular Parque do Zizo................................................... 8

2.2 Freqüência de atividades de caça de mamíferos silvestres..................... 14

2.2.1 Caracterização das atividades de caça na região................................... 14

2.3 Abundância das espécies de mamíferos de médio e grande porte.......... 15

2.3.1 Uso de parcelas de areia............................................................... 15

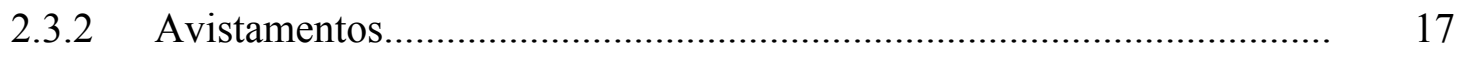

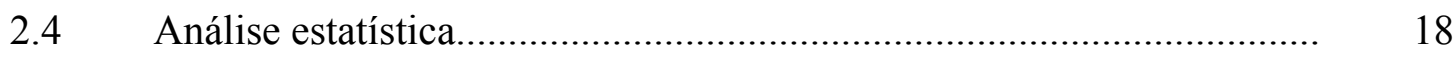

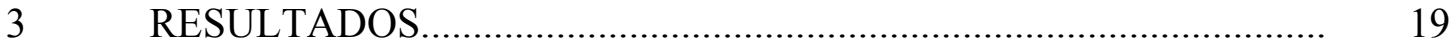

3.1 Observações diretas das atividades de caça......................................... 19

3.2 Entrevista com a população do entorno das áreas estudadas.................. 21

3.2.1 Perfil da caça no entorno do Parque Estadual Carlos Botelho................ 23 
3.2.2 Perfil da caça na região do Parque do Zizo.......................................... 25

3.2.3 Técnicas de caça utilizadas pelos moradores da região......................... 27

3.3 Freqüência de uso de recursos naturais segundo os relatórios da fiscalização do PECB........................................................................ 28

3.3.1 Extrativismo vegetal.................................................................. 30

3.3.2 Atividades de caça........................................................................ 31

3.4 Levantamento das espécies de mamíferos de médio e grande porte através de parcelas de areia............................................................. 34

3.5 O uso de diferentes tipos de registro em parcelas de areia .................... 36

3.6 Comparação da freqüência de ocorrência de mamíferos de médio e grande porte entre as áreas estudadas............................................... 37

3.6.1 Espécies agregadas em grupos funcionais (Guildas e Cinegéticos)....... 43

3.7 Avistamentos de mamíferos terrestres de médio e grande porte............. 47

$4 \quad$ DISCUSSÃO

4.1 Aspectos sócio-econômicos da população residente no entorno das

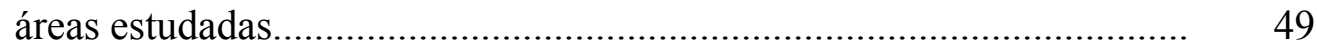

4.2 O uso de recursos naturais: caça e extrativismo vegetal........................ 50

4.3 Uso de parcelas de areia para o levantamento de espécies de mamíferos de médio e grande porte................................................ 52

4.3.1 Aspectos metodológicos: uso de diferentes tipos de registro em parcelas de areia............................................................................ 53

4.4 Avistamentos de mamíferos terrestres de médio e grande porte............. 56

4.5 Comparação da freqüência de ocorrência das espécies de mamíferos de médio e grande porte entre as áreas com diferentes pressões antrópicas................................................................................ 57

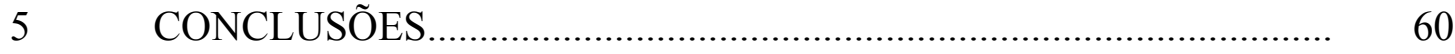

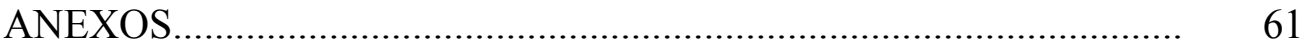

REFERÊNCIAS BIBLIOGRÁFICAS................................................. 64 


\section{LISTA DE FIGURAS}

Página

1 Localização das áreas no Brasil (A), no Estado (B) (fonte: Adaptado de Miranda \& Coutinho (2004)) e em detalhe (C). No detalhe, a composição colorida de imagem de satélite LANDSAT (2000) mostrando a ligação das áreas pelo contínuo de Floresta Atlântica. Em vermelho as áreas de amostragem das parcelas, avistamentos e caça $(\mathrm{S}=$ Sede e $\mathrm{T}=$ Turvinho).

2 Fotografia aérea com a localização dos plotes de areia nas trilhas da Sede (Fonte: Instituto Florestal, Divisão de Dasonomia)........................... 11

3 Fotografia aérea com a localização dos plotes de areia nas trilhas no Turvinho.

4 Fotografia aérea com a localização dos plotes de areia nas trilhas do

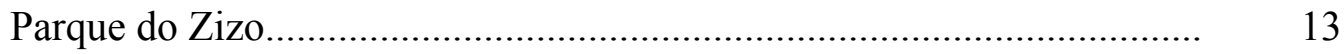

5 Acampamento de palmiteiros e caçadores encontrado no Parque do Zizo

6 Armadilha do tipo "chiqueiro" com ceva de milho para captura de paca (Agouti paca) encontrada na Base Turvinho

7 Riqueza de espécies de médios e grandes mamíferos nas trilhas das áreas

8 Figura 8 - Correlação entre os diferentes tipos de registros em parcelas de areia. Cada ponto representa o número total de registros de cada réplica (trilha) das três áreas estudadas. $r=$ Coeficiente de correlação de Spearman, $\mathrm{P}=$ probabilidade associada a este coeficiente, $\alpha=0,05$ (Bioestat 3.0) 
9 Freqüência de ocorrência temporal de cada espécie $(\mathrm{A}-\mathrm{I})$ e total de espécies $(\mathrm{J})$, utilizando o tipo de registro presença na trilha......................

10 Freqüência de ocorrência espacial de cada espécie $(\mathrm{A}-\mathrm{I})$ e total de espécies (J), utilizando o tipo de registro presença na parcela..................

11 Freqüência de ocorrência das Guildas e Cinegéticos nas trilhas, durante as sessões de vistoria, utilizando o tipo de registro presença na trilha.......

12 Freqüência de ocorrência Guildas e Cinegéticos nas trilhas, por sessão de vistoria, utilizando o tipo de registro presença na parcela....................

13 Número de registros de médios e grandes mamíferos em cada trilha, nas três sessões de coletas realizadas nas diferentes estações do ano.............. 


\section{LISTA DE TABELAS}

Página

1 Período de amostragem das parcelas de areia em cada área de estudo de janeiro a agosto de 2003 ............................................................ 18

2 Registros de evidências de caça neste estudo, por Pianca \& Prado (2001) e Cullen et al. (2000).

3 Caracterização dos moradores e das propriedades do entorno das áreas estudadas ( $\mathrm{n}=$ número de entrevistas) () = número de citações dos entrevistados.

4 Percentual de mamíferos cinegéticos citados como preferidos pelos entrevistados (n=número de entrevistas)..............................................

5 Percentual de mamíferos citados como os mais numerosos nas áreas estudadas pelos entrevistados ( $\mathrm{n}=$ número de entrevistas)......................

6 Registros de evidências e vestígios de extração ilegal de palmito (Euterpe edulis) no Parque do Zizo, segundo os relatórios da fiscalização do PECB

7 Registros de evidências e vestígios de extração ilegal de palmito (Euterpe edulis) na Base Turvinho, segundo os relatórios da fiscalização do PECB.

8 Registros de evidências e vestígios das atividades de caça no Parque do Zizo, segundo os relatórios da fiscalização do PECB...

9 Registros de evidências e vestígios das atividades de caça na Base Turvinho, segundo os relatórios da fiscalização do PECB 
10 Síntese dos registros de atividades de caça na região das áreas estudadas, segundo as observações diretas (Janeiro a Agosto de 2003) e os relatórios da fiscalização (2000 a 2003).

11 Espécies, características ecológicas e de uso de mamíferos de médio e grande porte registrados nas parcelas de areia das áreas estudadas.....

12 Número de registros da presença de cada espécie nas parcelas de areia, em cada trilha e total por área de estudo. As últimas duas colunas indicam o valor do teste de Kruskal Wallis (H) e probabilidade associada ao teste $(\mathrm{P}), \alpha=0,05$.

13 Número de registros da presença de cada espécie nas parcelas de areia, em cada trilha e total por área de estudo. As últimas duas colunas indicam o valor do teste de Kruskal Wallis $(\mathrm{H})$ e probabilidade associada ao teste $(\mathrm{P}), \alpha=0,05$.

14 Número de registros totais das espécies de mamíferos de médio e grande porte nas áreas estudadas, separadas em guildas e cinegéticos. As últimas duas colunas indicam o valor do teste de Kruskal Wallis $(\mathrm{H})$ e probabilidade associada ao teste $(\mathrm{P}), \alpha=0,05$.

15 Avistamentos de mamíferos de médio e grande porte registrados nas trilhas da área da Sede (80,2 km percorridos), Base Turvinho $(74,2) \mathrm{e}$ Parque do Zizo $(70,2 \mathrm{~km})$. 


\section{A CAÇA E SEUS EFEITOS SOBRE A OCORRÊNCIA DE MAMÍFEROS DE MÉDIO E GRANDE PORTE EM ÁREAS PRESERVADAS DE MATA ATLÂNTICA NA SERRA DE PARANAPIACABA (SP)}

Autora: CAMILA CAMARA PIANCA

Orientadora: Prof. ${ }^{a}$ REGINA TERESA ROSIM MONTEIRO

\section{RESUMO}

A Serra de Paranapiacaba tem o maior remanescente florestal contínuo de Mata Atlântica do Brasil. Poucos estudos sobre caça de animais silvestres foram realizados nesse bioma até o momento. Não existem dados a respeito de pressão de caça de mamíferos e eficiência na fiscalização em unidades de conservação no contínuo de Mata Atlântica do sudeste de São Paulo. Este estudo foi realizado em três áreas na Serra de Paranapiacaba: duas áreas no Parque Estadual Carlos Botelho - PECB (Sede e Base Turvinho) e uma na Reserva Particular Parque do Zizo - RPPZ. O objetivo deste estudo foi quantificar a freqüência de caça e de ocorrência de mamíferos de médio e grande porte, e avaliar as diferenças nas freqüências dos mamíferos nas áreas com diferentes intensidades de pressão de caça e fiscalização. A freqüência das atividades de caça nas áreas foi analisada com base em observações diretas e vestígios de caçadores, além de 
entrevistas com moradores do entorno das áreas e dados da fiscalização do PECB. Para registrar a freqüência de uso das áreas por mamíferos terrestres de médio e grande porte foi utilizado o método de parcelas de areia. Para as espécies arborícolas utilizou-se o método de transectos lineares para obtenção da taxa de avistamento das espécies e indivíduos nas áreas. Durante sete meses de estudo foram observados 17 registros de atividades de caça em duas das áreas estudadas, sendo seis no Zizo e 11 no Turvinho. Segundo os dados da fiscalização não ocorreram evidências de caça na Sede, e também no Zizo foram registradas menos evidências que no Turvinho. Cumpre destacar que ocorreram mais visitas da físcalização no Turvinho que no Zizo. A pressão de caça foi considerada moderada nas áreas onde a atividade foi registrada. Nas áreas de estudo foram registradas 20 espécies, sendo 15 por meio de parcelas de areia e cinco por avistamentos. Com um esforço amostral de 2700 parcelas monitoradas foram obtidos 426 registros de presença na parcela nas três áreas estudadas. Foi registrada maior freqüência de ocorrência nas parcelas e taxas de avistamento, tanto de espécies como de indivíduos na área da Sede, seguida do Turvinho e Zizo. Os onívoros foram mais freqüentes na Sede, com destaque para freqüente utilização das trilhas pelo (Cerdocyon thous) cachorro-do-mato, com 51,8\% do total de registros nas parcelas. Os herbívoros e as espécies cinegéticas foram mais registrados no Turvinho e os carnívoros no Zizo. A diversidade de espécies foi semelhante nas áreas estudadas, Sede e Turvinho $(n=11)$ e Zizo $(n=10)$. O maior número de registros nas parcelas foi obtido na estação seca. Estes resultados, associado ao atual contexto de pressões antrópicas na região, demonstram que áreas com uma menor freqüência de ocorrência de mamíferos de médio e grande porte, apresentam menor intensidade de fiscalização e maior pressão. Conclui-se que a eficiência da fiscalização pode ser importante na conservação de médios e grandes mamíferos na região, visto que mesmo nas áreas com pressão de caça moderada a presença da fiscalização contribui para uma maior freqüência de animais. 


\section{THE HUNTING AND ITS EFFECT ON THE OCCURRENCE OF MEDIUM AND LARGE MAMMALS IN PRESERVED AREAS OF BRAZILIAN ATLANTIC RAINFOREST IN THE SERRA DE PARANAPIACABA (SP)}

Author: CAMILA CAMARA PIANCA

Adviser: Prof. ${ }^{a}$ REGINA TERESA ROSIM MONTEIRO

\section{SUMMARY}

The Paranapiacaba mountain range has the greatest continuous remaining stretch of Atlantic Rainforest in Brazil. Few studies about hunting of wild animals in this ecosystem have been reported until this moment. There are no data regarding to hunting of mammals and fiscalization in preserved areas in the State of Sao Paulo southeastern continuous stretch of Atlantic Rainforest. This study has been developed in three areas in the Paranapiacaba mountain range: two areas in the Carlos Botelho State Park - PECB (Sede and Turvinho Base) and one in Zizo's Park Particular Reserve - RPPZ. The objective of this study was to quantify the frequency of hunting and of occurrence from mammals of medium and big size, as well as to evaluate the differences in the frequency of the mammals between areas with different intensities of hunting pressure and fiscalization. The hunting frequency in the areas in question was analyzed based in direct observations and vestiges of hunters, as well as interviews with residents of the areas boundaries and data of the PECB fiscalization. To register the frequency of the 
medium and large size terrestrial mammals it was used the sand parcel method. For the arboreal species was used the method of line transect to obtain the encounter rate of the species and individuals. During a seven months study seventeen registers of hunting activities were observed in two of the studied areas: six in Zizo and eleven in Turvinho. According to fiscalization data, hunting evidences didn't occurs in the Sede area, in the Zizo also was registered a small number of evidences comparing to Turvinho. The hunting pressure was considered moderate. In the areas studied were registered 20 species were registered in the studied areas: 15 of them by sand parcels and 5 by encounters. In an amostral effort of 2700 parcels monitored, 426 registers of presence in the parcels were registered of the three areas. The frequency registered of species and the encounter rate such as of species as individuals was bigger in the area of the Sede area, followed by Turvinho and Zizo. The omnivores were more frequent in the Sede area, with prominence for the frequent use of the trails by the crab-eating fox (Cerdocyon thous) with 51, 8\% of the total of the registers. The herbivores and the cinegetic species were more registered in the Turvinho, and the carnivores in the Zizo. The species diversity was similar in the areas, Sede and Turvinho $(n=11)$ and Zizo $(n=10)$. The biggest record number in the parcels was gotten in the dry station. These results, associate to current context of human pressures in the region, demonstrate that the areas with a lesser frequency of mammals, present minor fiscalization intensity and bigger pressure. The conclusions is that efficient fiscalization in the areas can be important in the conservation of medium and large mammals in the region, as it seems that, even in areas with moderate hunting pressure, the presence of fiscalization contributes for a bigger frequency of mammals. 


\section{INTRODUÇÃO}

Todos os biomas sofrem algum tipo de ameaça, porém o bioma Mata Atlântica abriga a segunda floresta tropical mais ameaçada do planeta, logo após a floresta da Ilha de Madagascar, na África. Na Mata Atlântica estão registradas 250 espécies de mamíferos (cerca de metade das espécies brasileiras), das quais 55 são exclusivas deste bioma, e 35 estão ameaçadas (Mittermeier et al., 2000; MMA, 2002). Tal diversidade e endemismo são superadas apenas pelas da Amazônia, que todavia não está tão ameaçada, e possui uma área muito mais extensa. Devido ao seu elevado grau de riqueza de espécies, endemismo e ameaça, a Mata Attântica é considerada uma das dez áreas do mundo mais prioritárias para conservação (Mittermeier et al., 1997; Myers et al., 2000).

A principal causa do declínio da população de mamíferos na Mata Atlântica tem sido a perda e fragmentação de hábitats (Fonseca et al., 1994; MMA, 2002), seguido da exploração direta de espécies, segunda causa mais importante de redução de populações naturais e extinções locais de animais ameaçados (Rosser \& Mainka, 2002) e mamíferos (Mace et al., 2000) no mundo.

Apesar das informações sobre a Mata Atlântica serem escassas, este padrão deve se manter, pois o bioma abarca as regiões de maiores densidades populacionais do Brasil, onde o extrativismo e a caça são práticas comuns nas suas áreas ainda florestadas. Apesar de proibida desde 1967 em todo território nacional (Código da fauna, Lei $N^{\circ}$ 5. 197/67), e de sua recente criminalização (Lei de Crimes Ambientais, Decreto 3179/1999), a caça de animais silvestres persiste na Mata Atlântica (e.g., Oliver \& Santos, 1991; Sanches 1997, IBAMA et al., 1998; MMA 2002 e Olmos et al.; 2002). 
Na Floresta Atlântica a caça é praticada por diferentes tipos de população, como tribos indígenas em diversas localidades.

Nas Reservas Indígenas é permitida a exploração da fauna silvestre como fonte de alimentação, porém ocorrem invasões de tribos advindas de países vizinhos em Unidades de Conservação de uso indireto (Galetti, 2001), causando conflitos em termos de permissão legal do uso de recursos naturais neste tipo de categoria de Unidade de Conservação, onde não é permitido o consumo, coleta, dano ou destruição destes recursos (SNUC, 2000).

Outras populações que caçam em áreas de Floresta Atlântica são os caiçaras na região litorânea (Sanches, 1997), colonos em diversas partes do país (Cullen, 1997; Ayres \& Ayres, 1979) e extrativistas ilegais de palmito Juçara (Euterpe edulis) na região da Serra de Paranapiacaba, Vale do Ribeira e Serra do Mar no Estado de São Paulo.

Segundo Sanches (1997) a técnica de caça mais comum no Brasil é o uso da arma de fogo, com auxílio de outras técnicas de captura (cão, iscas e "puleiro"); e as armadilhas, ("mundéu" e "laço"). Uma das estratégias de caça mais comuns é "espiar a ceva" (manter-se escondido para observar o animal se aproximar da isca), o que ocorre durante os intervalos entre as atividades cotidianas, e ao longo das incursões na floresta. Da mesma forma, o uso de arma de fogo pode ser oportunística, por exemplo, ao longo de caminhada, ou premeditada, em uma tocaia, como a espera em um "puleiro" (esconderijo em cima de árvores). Na caça por tocaia, são procurados locais propícios, como aqueles com fruteiras próximas, que sejam passagem do animal (carreiro) ou ainda onde existe algum tipo de abrigo típico de alguma espécie, onde em geral, deixa-se alguma isca ("ceva") para atrair mais facilmente a presa.

$\mathrm{O}$ "mundéu" é uma estrutura de taquaras e galhos pesados de árvores, armada sobre o solo e pode ser confeccionado de vários tamanhos, dependendo da espécie a ser caçada. Ao passar sob o "mundéu", a estrutura se desarma sobre o animal, prensando-o. Os caçadores preparam iscas ou armam os mundéus nos "carreiros" (caminho onde o animal passa deixando seus rastos), para atrair o animal mais facilmente para dentro da armadilha. As armadilhas de laço também são colocadas em carreiros ou com iscas (Sanches, 1997). 
Os estudos realizados no Brasil sugerem que os mamíferos em áreas de florestas tropicais em condições naturais, não são abundantes o suficiente para constituir fonte de alimentação para grandes populações humanas (Schubart, 1977; Peres 1990; Cullen, 1997; Cullen et al., 2000). A superexploração de mamíferos herbívoros e carnívoros pode pronunciar efeitos biológicos e mecânicos na estrutura e dinâmica das florestas tropicais, produzidos pela escassez ou extinção destes mamíferos. Os efeitos são relacionados à predação e dispersão de sementes, herbivoria e aumento na densidade de plântulas (Redford, 1992; Dirzo \& Miranda, 1991 e Roldán \& Simonetti, 2001). A ausência destas espécies pode causar também desequilíbrios na cadeia trófíca destes ecossistemas, como o aumento nas densidades de pequenos mamíferos pela falta de predadores e competidores.

\subsection{O efeito da caça sobre as populações animais}

A ação antrópica (caça, exploração madeireira e o desmatamento) exerce efeitos variados sobre as densidades das espécies animais. Segundo Robinson \& Redford (1991) a caça acarreta a diminuição das densidades das espécies de maior porte, que são mais visadas. Espécies de maior tamanho ocorrem em menores densidades do que as de menor porte, e espécies com dietas específicas e que ocupam níveis tróficos elevados possuem densidades mais baixas do que as espécies com dietas mais diversificadas. Se a pressão de caça for muito intensa, os animais com baixas densidades e baixas taxas reprodutivas poderão desaparecer, como foi observado com primatas por Peres (1990) no oeste da Amazônia.

Já a exploração madeireira, por alterar substancialmente a estrutura da floresta, provoca o aumento das espécies que se adaptam a ambientes perturbados. Alguns herbívoros, como veado (Mazama spp.), são beneficiados pela maior disponibilidade de gramíneas que surgem nas clareiras (Dourojeanni, 1985), enquanto que primatas pequenos são beneficiados pelo aumento de florestas secundárias (Johns \& Skorupa, 1987). Por outro lado, espécies mais sensíveis a alterações de hábitat têm suas densidades reduzidas. 
Redford (1992), utilizando dados secundários, estimou em $81 \%$ a diminuição da densidade de mamíferos não primatas devido à caça, e por ser seletiva, também modifica a composição da comunidade animal (Cullen, 1997; Cullen et al., 2000), de acordo com Calouro (1995) também têm suas densidades diretamente relacionadas com a adaptabilidade aos habitats e a disponibilidade de alimento.

Jerozolimski (1998) analisou 54 trabalhos sobre caça de subsistência desenvolvidos em nove países com florestas tropicais na América do Sul, verificando que a caça de subsistência afeta claramente a população de grandes mamíferos e que como resultado do aumento da pressão de caça o número de espécies utilizadas também aumenta.

Analisando a utilização de espécies da fauna silvestre na alimentação humana Cullen (1997) e Cullen et al. $(2000,2001)$ demonstram que mamíferos de grande e médio porte (porcos-do-mato, veado, pacas e tatus) são grupos preferenciais em áreas de fragmentos de Floresta Atlântica na região do Pontal do Paranapanema.

Infelizmente, os efeitos da caça sobre as populações animais ainda não são fáceis de serem quantificados. É necessário estimar a pressão de caça existente e os parâmetros populacionais básicos das principais espécies, para que seja possível avaliar o verdadeiro impacto da pressão de caça sobre essas populações (Calouro, 1995). Em florestas contínuas, como na Serra de Paranapiacaba, os efeitos de redução e desaparecimento de espécies demoram a aparecer, devido aos fluxos contínuos das espécies advindas de outras localidades.

Apesar da notória importância dos mamíferos na dinâmica de florestas tropicais, estudos sobre a dispersão e uso de habitat de mamíferos de médio e grande porte são raros, uma vez que são animais difíceis de capturar ou mesmo de visualizar, em função de seus hábitos discretos e das densidades relativamente baixas. Entretanto são fundamentais no estudo do efeito das pressões antrópicas na fauna em áreas naturais.

As pegadas são os sinais mais freqüentemente encontrados e de interpretação mais confiável. Além de fornecerem uma identificação precisa, muita vezes da espécie, rastros podem auxiliar em estudos de censo populacional, de territorialidade, de 
densidade relativa, de período e tipo de atividade e de estudos sobre predação (Becker \& Dalponte, 1991), em áreas com pressões de caça e fragmentação.

\subsection{Legislação brasileira e fiscalização do recursos naturais}

Segundo Bernardes et al. (1989), a caça de qualquer natureza está proibida desde 1967 através do código da fauna (Lei N ${ }^{\circ}$. 197/67) ${ }^{1}$ que contribuiu grandemente para redução da caça no Brasil, pois nela foi proibida a caça profissional, sendo a amadorista admitida somente em localidades onde as peculiaridades regionais o permitam, o que deve ser especificado em lei complementar. Segundo a Lei dos Crimes Ambientais de fevereiro de 1998 ( $\mathrm{N}^{\circ}$ 9.605, Art. 32) descriminaliza o abate de animais para saciar a fome do agente ou de sua família, para proteger lavouras ou rebanhos ou quando forem nocivos.

Em algumas comunidades rurais existem pessoas que não necessitam de caçar para saciar sua fome, mas usam esta justificativa embasada na lei para suas atividades de caça, dificultando o controle pela fiscalização ambiental. De acordo com Lorival e Fonseca (1997) a caça de subsistência é frequentemente praticada pela população rural no entorno de áreas florestadas sem fiscalização. Isso mostra uma posição de contrasenso, já que a legislação referente ao tema não está de acordo com as realidades regionais.

Na Serra de Paranapiacaba, Estado de São Paulo existem áreas que apresentam diferentes intensidades de atividades de caça de animais silvestres, onde a fiscalização dessas atividades também ocorre em diferentes intensidades, com uma grande discrepância na vigilância entre as áreas públicas e privadas.

Durante o ano de 1998 a fiscalização de rotina percorreu cerca de $60.000 \mathrm{~km}$ pelas trilhas do Parque Estadual Carlos Botelho e seu entorno imediato (Fonte: PECB, 1998). Enquanto na Reserva Particular Parque do Zizo no ano de 2000 foram feitas duas rondas na região da sede, pela Polícia Florestal de Itapetininga

\footnotetext{
${ }^{1}$ Artigo $1^{\circ}$ - Os animais de quaisquer espécies, em qualquer fase do seu desenvolvimento e que vivem naturalmente fora do cativeiro, constituindo a fauna silvestre, bem como seus ninhos, abrigos e criadouros naturais, são propriedades do Estado, sendo proibido sua utilização, perseguição, destruição, caça ou apanha.
} 
O programa de fiscalização desenvolve ação integrada permanente com a Polícia Ambiental de Itapetininga e Registro e com os Parques Estaduais Intervales, Turístico do Alto Ribeira e Jacupiranga, permitindo a maximização dos recursos materiais e humanos e garantindo a continuidade das ações de forma regular. Entretanto, são identificados problemas de infra-estrutura de trabalho, como a modernização do sistema de comunicação via rádio, necessidade de armamento e coletes a prova de bala para a segurança dos funcionários nas rondas de rotina, além da limitação de pessoal disponível (Ferraz e Varjabedian, 1999).

Este estudo pretende avaliar o uso das espécies de mamíferos de médio e grande porte pela população humana e seus efeitos na freqüência de ocorrência destes mamíferos silvestres em três áreas na Serra de Paranapiacaba (SP): duas áreas no Parque Estadual Carlos Botelho - PECB (Sede e Base Turvinho) e uma na Reserva Particular Parque do Zizo - RPPZ, comparando estas áreas com diferentes pressões antrópicas e fiscalização dos recursos naturais. Vale ressaltar que este é o primeiro inventário de mamíferos de médio e grande porte realizado na Reserva Particular do Parque do Zizo e Base Turvinho (PECB), além da primeira compilação de dados sobre fiscalização de recursos naturais na região.

Usando o grupo de mamíferos de médio e grande porte como estudo de caso, este trabalho tem como objetivos específicos:

a) Caracterizar a atividade de caça e quantificar a sua freqüência nas áreas de estudo.

b) Estimar a freqüência de ocorrência das espécies de mamíferos de médio e grande porte.

c) Avaliar a diferença na freqüência de ocorrência dos mamíferos e a intensidade de caça nas áreas de estudo. 


\section{MATERIAL E MÉTODOS}

\section{1 Área de estudo}

A região está inserida nas bacias hidrográficas do Ribeira de Iguape e Paranapanema. A vegetação é típica de Floresta Pluvial Tropical, correspondendo à formação de Floresta Ombrófila Densa Submontana/Montana (Moraes, 1993).

Este local apresenta duas áreas com tipos climáticos diferentes ( $\mathrm{Cfa}$ e $\mathrm{Cfb}$ ) separados pela Serra de Paranapiacaba (conforme KÖEPPEN). O tipo Cfa ou clima quente e úmido sem estiagem ocorre nas altitudes inferiores a $800 \mathrm{~m}$ (região de Sete Barras). O tipo climático $\mathrm{Cfb}$ ou clima temperado úmido sem estiagem ocorre nas partes mais elevadas da serra (São Miguel Arcanjo e Capão Bonito). A região possui temperaturas médias de $18^{\circ} \mathrm{C}$ a $22^{\circ} \mathrm{C}$ (Moraes, 1993).

\subsubsection{Parque Estadual Carlos Botelho}

O Parque Estadual Carlos Botelho (PECB) encontra-se na região sul do Estado

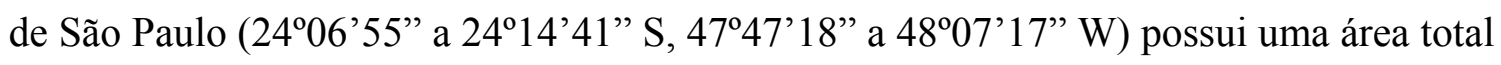
de 37.644,36 hectares, abrangendo os municípios de São Miguel Arcanjo, Sete Barras, Capão Bonito e Tapiraí (Figura 1). Possui uma amplitude altitudinal de 30 a 1200m. Integrado à Zona Núcleo da Reserva da Biosfera da Mata Atlântica - UNESCO, é abrigo natural para fauna e flora cuja taxa de diversidade é das mais altas registradas em todo país (Ferraz \& Varjabedian, 1999). 
O PECB apresenta duas características que o distingue das demais unidades que compõem o continuum ecológico da Serra de Paranapiacaba e Vale do Ribeira; a questão da regularização fundiária praticamente resolvida e a inexistência de população residente no interior do parque. Isto ajuda na efetiva conservação dos recursos naturais e facilita a fiscalização, que pode concentrar seus esforços no entorno do parque, onde atualmente ocorrem a maioria dos impactos humanos. No entorno do Parque existem vários núcleos humanos, em geral agricultores. O parque é cortado pela estrada SP-139, que não é asfaltada, e que tem $33 \mathrm{~km}$ de sua sede ao núcleo Sete Barras no município de Sete Barras (Figura 1). Nesta estrada freqüentemente se encontram vestígios de palmiteiros e caçadores, que são averiguados pela fiscalização do parque. Segundo os relatórios dos funcionários da fiscalização no período de 2000 a 2003, foram registradas 32 ocorrências entre extração de palmito e caça na área da estrada.

No Parque Estadual Carlos Botelho foram amostradas duas áreas, uma distante 5 $\mathrm{km}$ da sede e a Base Turvinho. A área da Sede localiza-se na parte centro-oeste do Parque, este local é utilizado somente por pesquisadores e não foram registrados vestígios de atividades de caça e extração de palmito desde a abertura das trilhas há mais de cinco anos (com. pess., Beatriz Beiseigel, 2002) (Figura 2). Nos relatórios da fiscalização do parque, não constam ocorrências de atividades ilegais nesta área. As trilhas na área utilizadas neste estudo foram abertas por pesquisadores do parque.

Na porção norte do PECB localiza-se a Base Turvinho, próxima à Represa São José, distante $7 \mathrm{~km}$ do Bairro do Turvinho e $25 \mathrm{~km}$ da Sede e da cidade de São Miguel Arcanjo. A represa é muito utilizada pela população do Bairro do Turvinho para caça e pesca. As trilhas abertas para este estudo encontram-se dentro do Parque, próximas à divisa com propriedades particulares (Figura 3). A fiscalização de rotina do PECB percorre da região a procura de indícios de atividades ilegais.

\subsubsection{Reserva Particular do Parque do Zizo}

A Reserva Particular Parque do Zizo (RPPZ) possui uma área de 400 hectares, e encontra-se na divisa do município de São Miguel Arcanjo com o município de Tapiraí 
$\left(24^{\circ} 00^{\prime} 56^{\prime \prime} \mathrm{S}\right.$ e $\left.47^{\circ} 48^{\prime} 44^{\prime \prime} \mathrm{W}\right)$. Esta região situa-se próximo às porções mais altas da Serra de Paranapiacaba, com altitudes variando entre 500 e 800 metros. Distante $30 \mathrm{~km}$ do centro do município de São Miguel Arcanjo, o Parque do Zizo faz parte do entorno do Parque Estadual Carlos Botelho e está em processo de transformação em RPPN (Reserva Particular do Patrimônio Natural) (Figura 1).

$\mathrm{Na}$ Reserva Particular Parque do Zizo foram utilizadas as trilhas já existentes e percorridas para o levantamento de espécies de mamíferos de médio e grande porte (Figura 4), que constatou a presença de uma mastofauna bastante íntegra. Nesta área é constante o encontro de vestígios de atividades de caça e extração de palmito e na maioria destas trilhas não ocorre fiscalização, devido ao difícil acesso ao local.

No entorno da Reserva existem grandes áreas particulares ainda florestadas e o local é pouco povoado, com apenas 12 residências de pequenos agricultores, palmiteiros e caçadores. Ao longo da estrada de acesso para a reserva, existem plantações de pinheiros e eucaliptos. Estas plantações abrigam espécies de mamíferos de médio e grande porte, tais com a anta, veado e onça-parda. Devido a esta característica de possuir ainda uma considerável matriz florestal no seu entorno, a Reserva tem um grande potencial para contribuir na conservação da diversidade de mamíferos in situ na região.

Contudo, mesmo com todo esse potencial de conservação da região, as pressões antrópicas persistem. A Reserva é freqüentemente invadida por palmiteiros, que cortam o palmito mesmo em locais muito próximos à sede, onde se encontram os funcionários, mostrando o quanto eles se sentem à vontade para invadir a propriedade e extrair ilegalmente o palmito. A ausência de fiscalização no local agrava o problema, pois à medida que acabam as palmeiras maiores, eles voltam para cortar os indivíduos jovens.

Tanto na RPPZ como no PECB ocorrem impactos humanos típicos da região, como a caça de animais silvestres e extração de palmito. Porém o PECB apresenta áreas onde estas atividades extrativistas ocorrem em diferentes intensidades. Já em menor freqüência, verificou-se nas duas localidades a atividade de garimpo esta sempre relacionada à extração de ouro nos córregos (Relatórios da fiscalização PECB). 

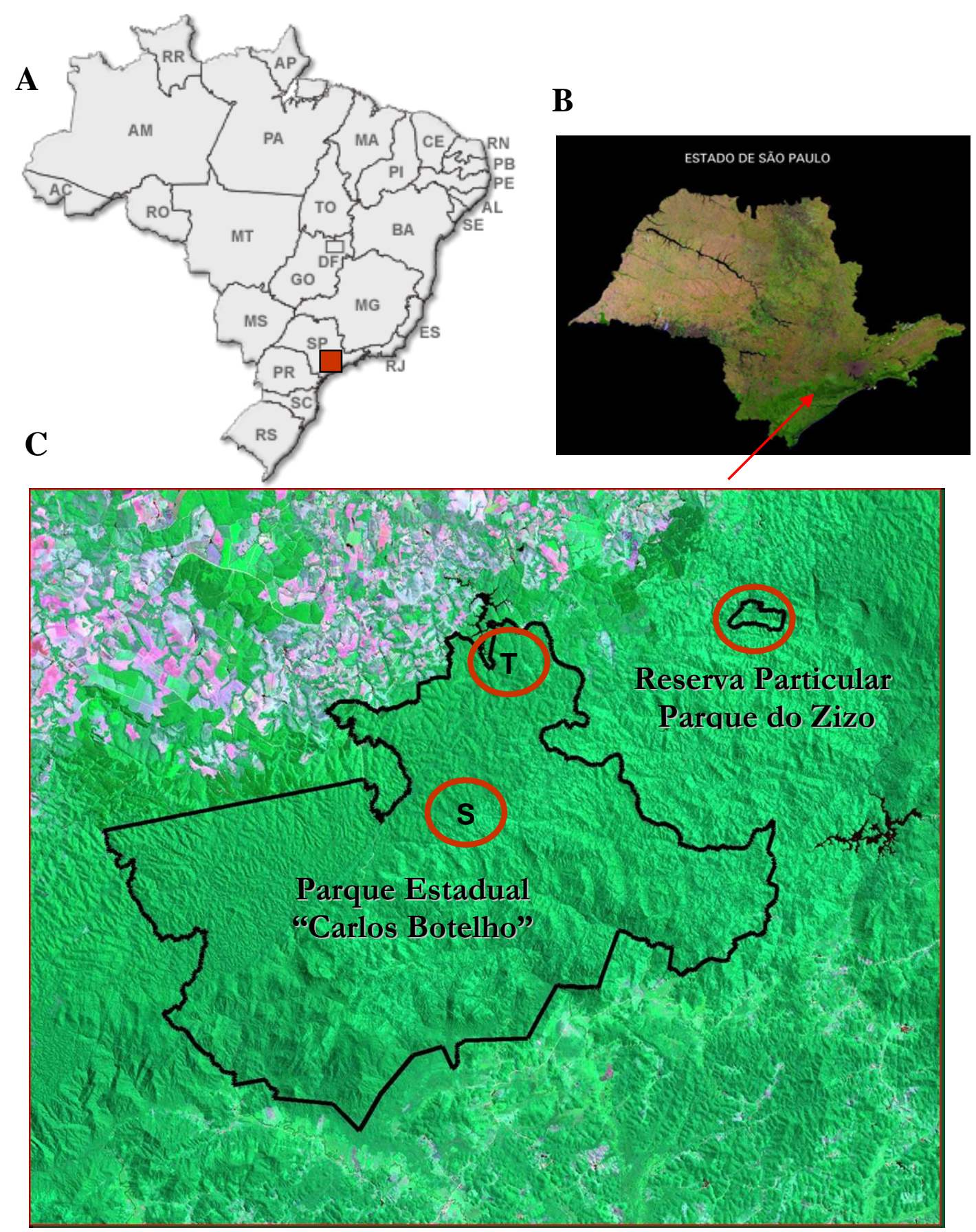

Figura 1 - Localização das áreas no Brasil (A), no Estado (B) (fonte: Adaptado de Miranda \& Coutinho (2004)) e em detalhe (C). No detalhe, a composição colorida de imagem de satélite LANDSAT (2000) mostrando a ligação das áreas pelo contínuo de Floresta Atlântica. Em vermelho as áreas de amostragem das parcelas, avistamentos e caça $(\mathrm{S}=\mathrm{Sede}$ e $\mathrm{T}=$ Turvinho $)$ 


\section{Sede Parque Estadual Carlos Botelho}

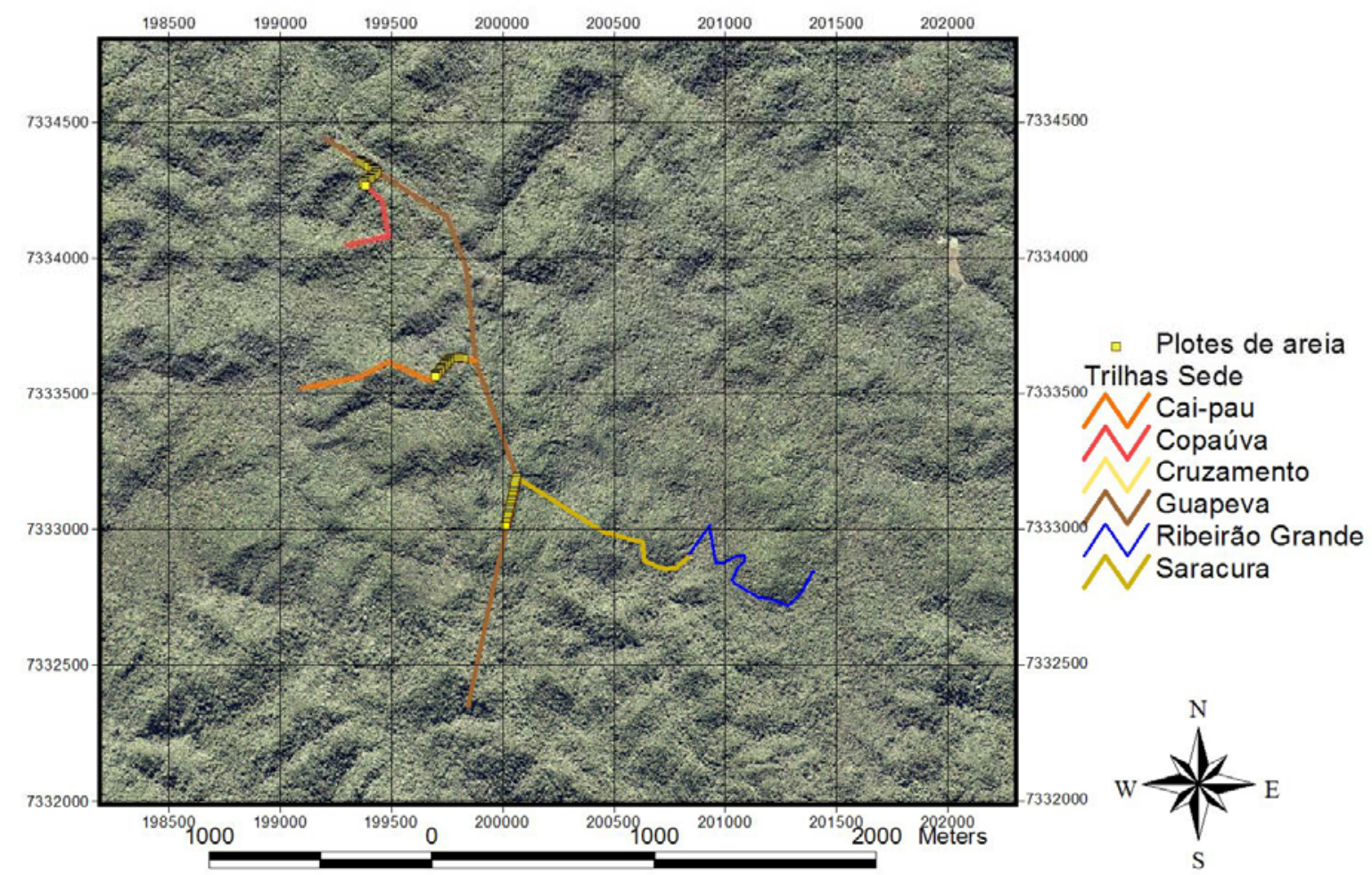

Figura 2 - Fotografia aérea com a localização dos plotes de areia nas trilhas da Sede (Fonte: Instituto Florestal, Divisão de Dasonomia)

- Trilha da Guapeva: extensão: $3.5 \mathrm{~km}$. Distante $5 \mathrm{~km}$ da sede, tem acesso pela estrada de serviço do parque utilizada para fiscalização. Possui em seus primeiros trechos mata secundária tardia, com a presença de bambuzais. Esta trilha é muito antiga, foi utilizada para extração de madeira para fabricação de carvão nas décadas de 60 e 70 . Esta é a trilha mestre do local, de onde partem todas as outras.

- Trilha Cai-Pau: extensão: $1 \mathrm{~km}$ Esta trilha começa a 1500m do início da T. guapeva. Localiza-se na vertente oeste e depois se estende praticamente toda sua extensão no topo do morro, terminando no vale do Rio Guapeva. Possui mata madura em praticamente toda sua extensão.

- Trilha Copaúva: extensão: $600 \mathrm{~m}$. Esta trilha inicia-se a $700 \mathrm{~m}$ do início da T. guapeva. Os primeiros 200 metros situam-se em topo de morro e depois se estende pela vertente sul, terminando no vale do Córrego Vermelho. Possui mata madura em toda sua extensão.

- Trilha do Rio Guapeva: extensão: 2,5 km. Esta trilha estende-se pelo Vale do Rio Guapeva, com inúmeras trilhas que se conectam através das vertentes dos morros e cabeceiras dos córregos até a Trilha da Guapeva. Possui mata "madura" em toda sua extensão, com grande quantidade de palmiteiros maduros, jovens e plântulas.

- Trilha do Ribeirão Grande: extensão: $3 \mathrm{~km}$. Localiza-se a $2 \mathrm{~km}$ do início da T. da Guapeva. Possui uma mata "madura" e à medida que avançamos para a cabeceira do Ribeirão Grande aumenta a presença de bambuzais. 


\section{Base Turvinho}
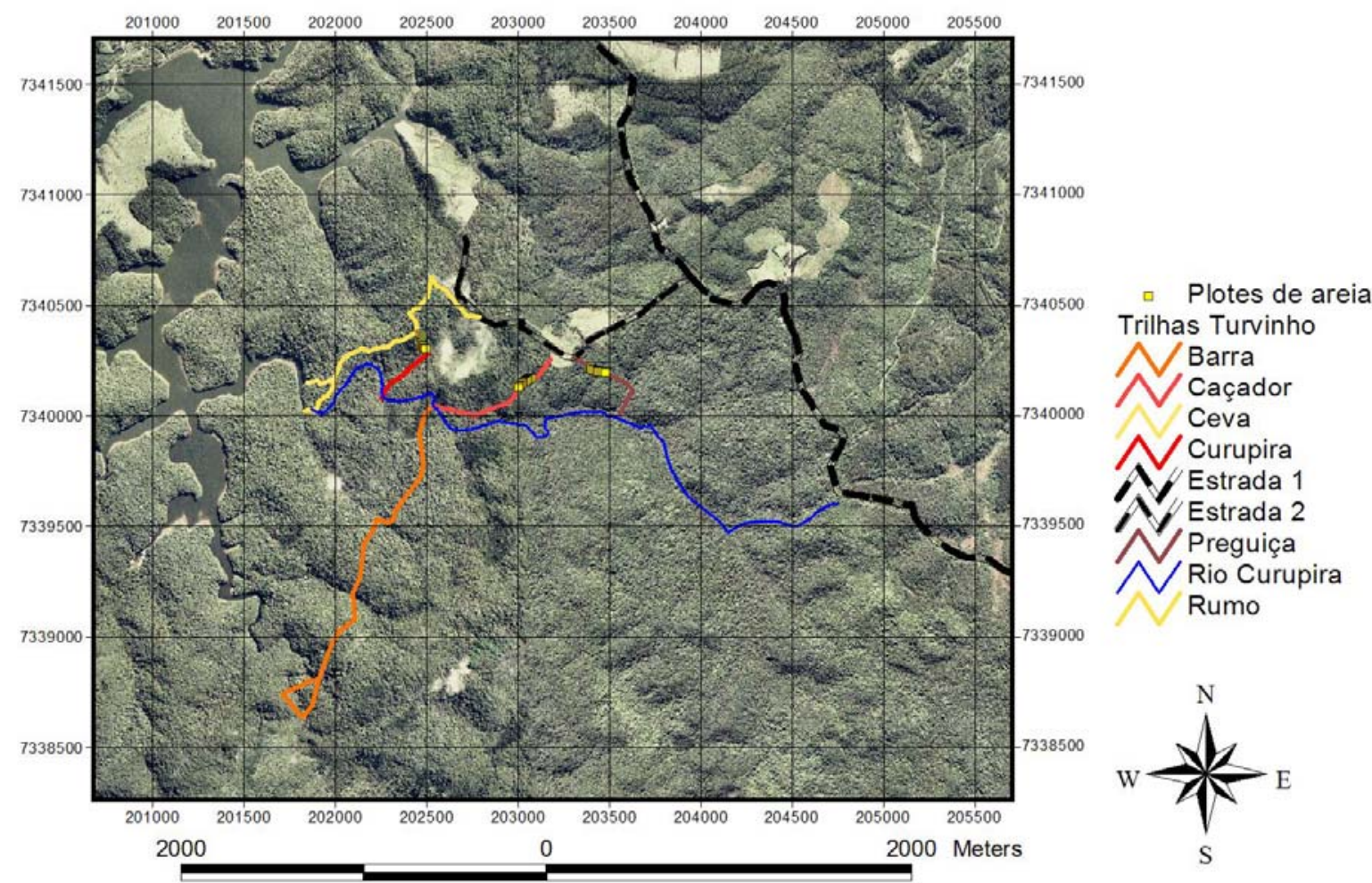

Figura 3 - Fotografia aérea com a localização dos plotes de areia nas trilhas no Turvinho

- Trilha do Curupira: extensão: $700 \mathrm{~m}$. Esta trilha começa a $800 \mathrm{~m}$ do Rumo e está localizada na vertente do morro da margem esquerda do Rio Curupira. Esta é uma trilha antiga, conhecida pelos moradores há vários anos e utilizada por palmiteiros, como indica o corte antigo de palmitos observados e registrados nos relatórios da fiscalização do parque.

- Trilha do Caçador: extensão: $700 \mathrm{~m}$. No início da trilha $(150 \mathrm{~m})$ ocorre mata secundária, após este trecho a mata pode ser considerada madura. Esta também é uma trilha utilizada para caçar e extrair palmito. Esta trilha termina em um puleiro de caça de aproximadamente $3 \mathrm{~m}$ de altura na beira do Rio Curupira.

- Trilha da Preguiça: extensão: $350 \mathrm{~m}$. Esta trilha é a mais curta da área, possui mata secundária tardia nos trechos iniciais $(50 \mathrm{~m})$ e depois mata madura. Esta trilha termina no Rio Curupira onde é possível se conectar com as demais trilhas de estudo descendo o rio.

- Trilha do Rumo: extensão: 1,5 km. O rumo é a divisa do PECB com a Fazenda Santa Helena, até a Represa São José. Esta fazenda é uma das maiores propriedades do local com plantações de eucalipto. O rumo é constantemente limpo pelos funcionários do parque e muito utilizado pela equipe de fiscalização na região. Porém, também é o caminho usado pela população chegar à represa.

- Trilha do Rio Curupira: extensão: 3,5 km. Localiza-se na margem do Rio Curupira, tem início na estrada a $1 \mathrm{~km}$ da Base Turvinho. Possui mata secundária em vários trechos, além de uma clareira com a vegetação em regeneração, onde havia uma residência de antes da transformação da área em unidade de conservação estadual. 


\section{Parque do Zizo}

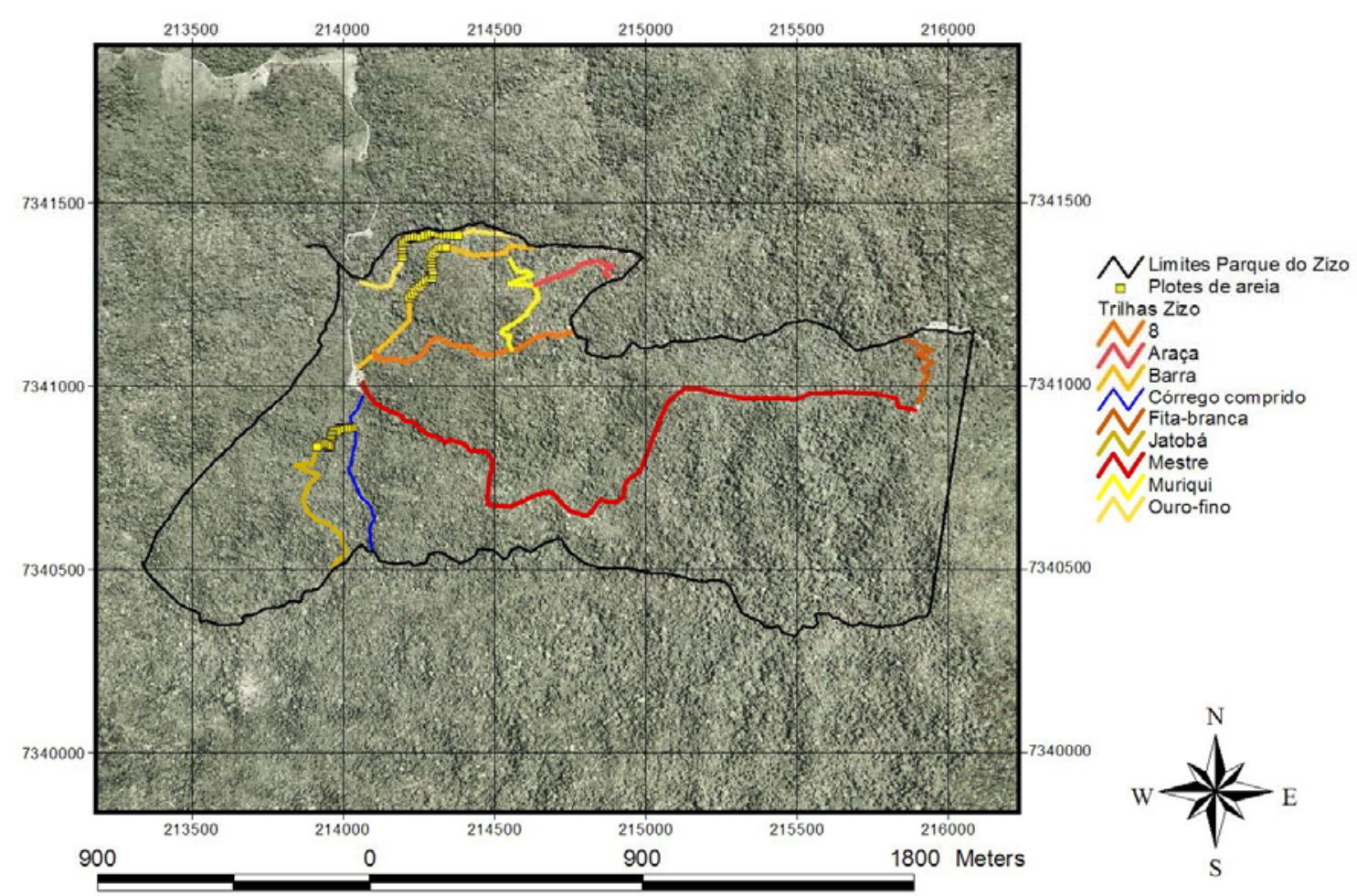

Figura 4 - Fotografia aérea com a localização dos plotes de areia nas trilhas do Parque do Zizo

- Trilha da Barra: extensão 700m. Esta trilha começa na sede da reserva e termina na barra dos rios Ouro-fino e Baú, após a junção de suas águas recebe o nome de rio Pedro Vaz. Em seus primeiros $200 \mathrm{~m}$ há presença de um grande bambuzal, onde a mata está em regeneração, após este trecho a mata apresenta-se em estágio maduro.

- Trilha do Ouro-fino: extensão $770 \mathrm{~m}$. Esta trilha começa na ponte do rio Ouro-fino e termina na cachoeira do rio Ouro-fino, próximo da barra. Possui mata secundária em seus trechos iniciais na margem do rio.

- Trilha do Jatobá: extensão 900 m. Inicia-se no ponto 100 (m) da T. do Pau-oco e termina no Rio Quebra-Cabeça. Possui mata primária em alguns trechos misturada à mata secundária proveniente da abertura de clareiras pela queda de grandes árvores.

- Trilha do Rio Pedro Vaz: extensão $4 \mathrm{~km}$. Situa-se ao lado do rio Pedro Vaz, este rio também é divisa norte do parque, representado na figura pela linha preta. Possui mata primária em quase toda sua extensão com locais de grande quantidade de bambuzais e palmitos cortados.

- Trilha Mestre: extensão $2.700 \mathrm{~m}$. Esta trilha possui a largura de 4 metros e foi uma antiga estrada construída na década de 70 para extração de madeira para produção de carvão. Possui mata secundária em grande parte de sua extensão e com presença de bambuzais em praticamente toda sua extensão. 


\subsection{Freqüência de atividades de caça de mamíferos silvestres}

As observações diretas de vestígios foram quantificadas no entorno e nas trilhas das áreas durante o período de Janeiro a Agosto de 2003. As áreas de estudo foram classificadas de acordo com a pressão de caça (ausente, moderada e forte), estas categorias foram determinadas pelo número de residências próxima às áreas, como medida de presença humana, som de tiros ouvidos durante os transectos, cachorros de caça, puleiros nas trilhas, armadilhas para mamíferos de médio e grande porte e observações diretas de caçadores na área como utilizaram Cullen (1997) e Cullen et al, (2000).

Os dados secundários foram obtidos com a Diretoria do PECB. A Equipe de fiscalização do Parque preenche relatórios diários com a descrição das rondas de patrulha no parque e seu entorno (Anexo A). São averiguadas e listadas as atividades relacionadas à extração ilegal de recursos naturais, tais como caça, corte de palmito e mineração de ouro. Com base nestes relatórios, foi analisada a frequência de ocorrência de atividades de caça nas áreas estudadas e entorno, durante o período de 2000 a 2003. Este estudo é a primeira compilação deste tipo de dados na região.

\subsubsection{Caracterização das atividades de caça na região}

A caça foi caracterizada com entrevistas aplicadas à população local do entorno das áreas de estudo como utilizado por Ayres \& Ayres (1979), Becker (1981) e Sanches (1997). Foram realizadas, no total, 19 entrevistas, somente um entrevistado não mostrou interesse. As entrevistas foram realizadas nas propriedades localizadas, nas principais estradas de acesso as áreas de estudo. Este número de entrevistas representa toda a população residente no entorno imediato destas estradas, distante $5 \mathrm{~km}$ das áreas de estudo. Destas, nove foram no entorno da RPPZ e 10 no entorno do PECB (cinco no entorno da Sede e cinco no entorno da Base Turvinho). 
Foram levantadas variáveis de caracterização sócio-econômica, atividades da propriedade, tempo de residência na região, ocupação de trabalho e caracterização das atividades de caça (Anexo B).

Algumas entrevistas abertas com a população do entorno das áreas permitiram criar um perfil das atividades de caça nas áreas, através do conhecimento local sobre a caça de animais silvestres, técnicas utilizadas, preferências alimentares, localidades de caça e diminuição de espécies. Como observado em outros estudos abordando o mesmo tema (Becker, 1981; Martins, 1992; Calouro, 1995 e Sanches, 1997) verificando as principais diferenças no contexto de áreas naturais protegidas com e sem fiscalização efetiva.

\subsection{Abundância das espécies de mamíferos de médio e grande porte}

\subsubsection{Uso de parcelas de areia}

Em todas as áreas de estudo foi utilizado o método de registro, identificação e quantificação de pegadas. Este método consiste na distribuição de parcelas $(50 \times 50 \mathrm{~cm})$ de areia fina no ambiente em estudo, seguida de verificações periódicas para identificação dos rastros impressos (Deixo \& Miranda, 1990, 1991; Silva, 2001; Caos, 2002; Pardini, 2001 e Pardini, et al., 2004). Neste estudo não foram utilizadas iscas nas parcelas de areia para atração dos animais.

A areia é um substrato adequado para a impressão de pegadas de animais como edentados (tatus e tamanduás), roedores (cotias, paca e capivara), ungulados (anta, porcos do mato e veados) e carnívoros (onça, gatos do mato, guaxinim, irara e coati) (Dirzo \& Miranda, 1991; Pardini, et al., 2004). As pegadas foram identificadas através do guia de "Mamíferos Silvestres Brasileiros" (Becker \& Dalponte, 1991). Em cada parcela de areia de cada trilha foi registrado:
a) espécie;
b) comprimento, largura da pegada e da passada;
c) número e direção de rastros. 
Para o registro da freqüência de ocorrência dos mamíferos, foram escolhidas três trilhas com característica gerais semelhantes (vegetação madura predominante, largura da trilha e proximidade com cursos d água) em cada área de estudo. Em cada trilha foram colocadas 20 parcelas de areia, a intervalos de 10 metros, totalizando 60 parcelas de areia em cada área de estudo (Sede, Turvinho e Zizo) (Figuras 2, 3 e 4). Foram feitas três sessões de vistorias em cada área de estudo (Tabela 1). Em cada sessão as parcelas foram verificadas diariamente e seus rastros apagados, durante cinco dias consecutivos, totalizando 900 parcelas-noite em cada área e 2700 parcelas-noite nas três áreas estudadas. Procurou-se diminuir ao máximo os intervalos de tempo entre uma área e outra, para tentar minimizar os efeitos de diferenças climáticas.

Para cada área a freqüência das espécies foi calculada com a soma do número de registros nas três sessões de vistoria. Os tipos de registros de pegadas nas parcelas de areia em cada trilha foram:

- Pegadas: soma de pegadas em cada parcela por dia;

- Passagens: registro em diferentes direções em cada parcela por dia, independente do número de pegadas;

- Presença: registro em cada parcela por dia, independente da direção e número de pegadas;

- Presença na trilha: registro uma parcela da trilha por dia, independente da direção e número de pegadas.

Os estudos com o método de parcelas de areia (Dirzo \& Miranda, 1990; Pardini, 2001; Silva, 2001; Scoss, 2002; Pardini et al., 2003) em geral, utilizam o tipo de registro “presença na parcela”, enquanto outros estudos (Engeman \& Allen, 2000; Bider, 1968) consideram o tipo de registro "passagem na parcela" mais adequado para medir parâmetros de atividade de uma determinada espécie, porém poucos estudos comparam os resultados obtidos usando diferentes tipos de registro, método abordado neste trabalho. 


\subsection{2 - Avistamentos}

Foi utilizado o método padronizado de transectos lineares, largamente utilizado para levantamentos populacionais em florestas tropicais (Burnham et al., 1980; NCR, 1981; Buckland et al., 1993; Mateos \& Mañosa, 1996; Bodmer et al., 1990; Peres, 1990; Chiarello, 1999; Ojasti, 2000; Cullen et al., 2000) para obtenção das taxas de avistamento das espécies de primatas (Cebus, Alouatta e Brachyteles) e outras espécies de mamíferos de médio e grande porte. Devido ao seu hábito arborícola, estas espécies de primatas não são registradas pelo método de parcelas de areia, e como utilizam essencialmente os mesmos estratos verticais da vegetação são relativamente fáceis de observar no meio da floresta.

Os transectos foram distribuídos nas trilhas das áreas de estudo distantes $500 \mathrm{~m}$ entre si (Figura 2, 3 e 4) e nas estradas no entorno das áreas de estudo, foi anotado as observações diretas dos animais e a distância percorrida somente na ida. Os transectos foram realizados pela manhã, das 07:00 às 11:30 h, e à tarde, das 14:00 às 18:00 h, com uma velocidade média de caminhada de $1 \mathrm{~km} / \mathrm{h}$. Na Sede foi percorrido $80,2 \mathrm{~km}$, no Turvinho 74,2 km e no Zizo 70,2 km, totalizando $225,1 \mathrm{~km}$. O período amostral foi durante as sessões de vistoria das parcelas de areia (Tabela 1). Em cada transecto foi registrado:
a) espécie;
b) número de indivíduos de cada grupo (n);
c) distância percorrida $(\mathrm{km})$.

Os avistamentos de mamíferos de médio e grande porte foram analisados através da taxa de avistamento, que consiste no número de avistamentos das espécies e de indivíduos cada $10 \mathrm{~km}$ percorridos. O cálculo foi obtido através do número de avistamentos multiplicado por $10(\mathrm{~km})$ dividido pela quilometragem total percorrida em cada área/espécie/indivíduos do grupo. 
Tabela 1. Período de amostragem das parcelas de areia, avistamentos e quantificação das atividades de caça em cada área de estudo de janeiro a agosto de 2003

\begin{tabular}{cccc}
\hline Amostragem & Sede & Turvinho & Zizo \\
\hline Sessão 1 & 02 a 06/02 & 26 a 30/01 & 18 a 22/02 \\
Sessão 2 & 07 a 13/03 & 25 a 29/03 & 08 a $14 / 05$ \\
Sessão 3 & 15 a 20/07 & 30 a 05/07 & 02 a 07/08 \\
\hline
\end{tabular}

\section{4 - Análise estatística}

Para determinar o grau de associação entre os tipos de registro e definir o mais adequado para a comparação das freqüências das espécies entre as áreas, foi utilizado o coeficiente de correlação de Spermam (r). Para obtenção da freqüência das espécies, em cada área, o número de registros das parcelas e sessões de vistoria foi somado para determinar a intensidade de uso das áreas.

Para verificar se houve diferença na freqüência de registros das espécies entre as áreas estudadas, das espécies agregadas em guildas: Carnívoros (dieta estritamente carnívora), herbívoros (Frugívoro/Folívoro), onívoros (Frugívoros/insetívoros) e mirmecófago e diferenças na freqüência das espécies utilizadas na alimentação humana (cinegéticas) foi utilizado o teste de Kruskal Wallis. As espécies e características ecológicas foram classificadas segundo Fonseca et al. (1994).

As sessões de vistoria foram realizadas em diferentes épocas do ano, na estação chuvosa (sessão 1), no outono (sessão 2) e na estação seca (sessão 3) (Tabela 1). A análise estatística também foi aplicada para testar a diferenças entre as sessões de vistoria separadas em estação. As análises estatísticas foram feitas utilizando o software Bioestat 3.0. 


\section{RESULTADOS}

\subsection{Observação direta das atividades de caça}

Um estudo realizado no Parque do Zizo por Pianca \& Prado (2001, não publicado) ${ }^{2}$ mostrou que esta área sofre uma pressão de caça equivalente ou mesmo superior às observadas por Cullen et al. (2000) em fragmentos florestais sob caça intensa no Pontal de Paranapanema.

No Parque do Zizo o esforço amostral, expresso em extensão de trilhas percorridas, foi oito vezes menor que o realizado no Pontal do Paranapanema (Tabela 2). Contudo, na região do Parque do Zizo, que tem uma população de entorno menor, registramos um número de evidências de caça bem próximo, e em alguns casos maior, do que o obtido na região do Pontal.

Durante o período de estudo de janeiro a agosto de 2003 foram registradas atividades de caça em duas das áreas estudadas $(n=17)$, sendo seis no Parque do Zizo e onze na Base Turvinho (PECB). Nas trilhas percorridas na Sede (PECB) não foi registrada nenhuma evidência durante o período de estudo. Durante os oito meses de estudo foram registradas poucas evidências de atividades de caça nas áreas estudadas se comparado ao ano de 2001 na Reserva Particular do Parque do Zizo (Tabela 2).

Esses dados mostram que a fiscalização e o aumento da presença humana (turistas, pesquisadores e funcionários do parque) em ambas as áreas de estudo, estão refletindo na diminuição destas evidências. Durante este período a pressão de caça foi considerada moderada, em relação ao ano de 2001 no Parque do Zizo e na área com maior pressão no Pontal do Paranapanema.

2 PIANCA, C.C. \& PRADO, P..I. Levantamento de mamíferos e sua caça em uma área preservada de Mata Atlântica na Serra de Paranapiacaba, Sudeste de São Paulo - Projeto Floresta e Mar - "Usos e Conflitos no Vale do Ribeira": NEPAM - Núcleo de Estudos e Pesquisas Ambientais, UNICAMP, 2001. 15p. (Relatório CT-III - FAPESP (Proc. 97/14514-1). 
Comparando o total de evidências de atividades de caça nos anos de 2001 e 2003 no Parque do Zizo, nota-se a diminuição destes indícios na área, provavelmente devido a freqüente presença de funcionários e turistas na área. Este foi o primeiro estudo sistemático de impactos humanos, realizado na área da Base Turvinho no Parque Estadual Carlos Botelho.

Tabela 2. Registros de evidências de caça neste estudo, por Pianca \& Prado (2001) e Cullen et al. (2000).

\begin{tabular}{lccccc}
\hline Áreas & Sede & Zizo & Turvinho & Zizo & Tucano \\
Período de estudo & \multicolumn{3}{c}{ presente estudo } & 2001 & 1996 \\
Número/Esforço amostral $(\mathrm{km})$ & 80,7 & 74,2 & 70,2 & 43 & 357 \\
\hline Moradias próximas 5 Km & 3 & 12 & 7 & 12 & 48 \\
Encontros com caçadores & 0 & 0 & 1 & 6 & 4 \\
Cachorros de caçadores & 0 & 1 & 4 & 2 & 8 \\
Sons de tiros & 0 & 2 & 2 & 2 & 2 \\
Registros de vestígios de caça & 0 & 2 & 2 & 5 & - \\
Acampamentos de caçadores ${ }^{1}$ & 0 & 1 & 3 & 4 & 5 \\
Armadilhas encontradas & 0 & 0 & 2 & 1 & - \\
Total & 3 & 18 & 21 & 32 & 62 \\
\hline
\end{tabular}

${ }^{1}$ Na região do Pontal do Paranapanema os acampamentos são puleiros feitos em árvores, no Parque do Zizo são barracos de madeira e no Turvinho ocorrem os dois tipos de acampamentos. 


\subsection{Entrevista com a população no entorno das áreas estudadas}

Tabela 3. Caracterização dos moradores e das propriedades do entorno das áreas estudadas ( $\mathrm{n}=$ número de entrevistas)

() = número de citações dos entrevistados

\begin{tabular}{|c|c|c|c|}
\hline Variáveis & Sede $(n=5)$ & Base Turvinho $(n=5)$ & Parque do Zizo (n=9) \\
\hline Idade & 24 a 65 anos & 40 a 67 & 40 a 82 \\
\hline Ocupação / Trabalho & $\begin{array}{l}\text { Caseiros (4) e proprietário } \\
\text { aposentado (1) }\end{array}$ & $\begin{array}{l}\text { Caseiros (4) e proprietário }{ }^{1} \\
\text { aposentado (1) }\end{array}$ & $\begin{array}{l}\text { Caseiros (4), proprietários }{ }^{1}(4) \mathrm{e} \\
\text { posseiro (1). }\end{array}$ \\
\hline Renda & $\begin{array}{l}\text { Igual ou superior a um salário } \\
\text { mínimo }(\mathrm{R} \$ 240,00)\end{array}$ & $\begin{array}{l}\text { Igual ou inferior a um salário } \\
\text { mínimo }\end{array}$ & $\begin{array}{l}\text { Desempregados (2), renda } \\
\text { inferior a um salário mínimo (5) } \\
\text { e acima (2). }\end{array}$ \\
\hline Tempo de residência & menos de 15 anos & 3 a 70 anos & 2 a 67 anos \\
\hline Tamanho da propriedade & 7 a 312 hectares & 20,4 a 4.800 hectares & 3 a 400 hectares \\
\hline Atividades nas propriedades & $\begin{array}{l}\text { Turismo, agricultura e criação de } \\
\text { bovinos }\end{array}$ & Agricultura, lazer e preservação & $\begin{array}{l}\text { Agricultura, turismo e } \\
\text { preservação }\end{array}$ \\
\hline Culturas & $\begin{array}{l}\text { Subsistência: Milho, feijão, } \\
\text { abóbora e pomar de frutas } \\
\text { Comercial: Uva }\end{array}$ & $\begin{array}{l}\text { Subsistência: Banana, arroz, } \\
\text { mandioca e feijão }\end{array}$ & $\begin{array}{l}\text { Subsistência: Banana, feijão, } \\
\text { mandioca, batata, milho, cana- } \\
\text { de-açúcar. }\end{array}$ \\
\hline Criações & $\begin{array}{l}\text { Cachorros (5), Galinha (2), } \\
\text { coelho (1), peru, marreco e } \\
\text { pavão (1), cavalo e gado (1) e } \\
\text { criação de peixes (1) }\end{array}$ & $\begin{array}{l}\text { Galinha (4), cachorro (4), ganso } \\
\text { (2), porco-do-mato e javali ( } 1 \text {, } \\
\text { cavalo (1) e peru (1) }\end{array}$ & $\begin{array}{l}\text { Cachorro (6), Cavalo (5), } \\
\text { Galinhas (3), ganso (3) e gatos } \\
\text { (2) }\end{array}$ \\
\hline Atividades de caça & $\begin{array}{l}\text { não caçam e não permitem a } \\
\text { caça nas propriedades }\end{array}$ & $\begin{array}{l}\text { A maioria afirma já ter caçado } \\
\text { antigamente }\end{array}$ & Subsistência \\
\hline $\begin{array}{l}\text { Animais caçados observados } \\
\text { nas entrevistas }\end{array}$ & 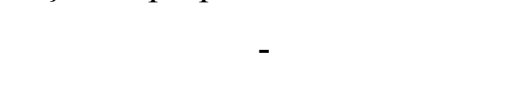 & - & $\begin{array}{l}\text { Veado, paca, coati, gambá, juriti } \\
\text { e macuco }\end{array}$ \\
\hline Animais citados como raros & nenhum & Queixada, lontra e a jacutinga & Queixada, cateto e jacutinga \\
\hline Fiscalização & Eficiente (5) & Ineficiente (4) & Ineficiente (9) \\
\hline
\end{tabular}


Tabela 4. Percentual de mamíferos cinegéticos citados como preferidos pelos entrevistados ( $\mathrm{n}=$ número de entrevistas)

\begin{tabular}{|c|c|c|c|c|}
\hline Espécie & $\begin{array}{l}\text { Sede } \\
(n=5)\end{array}$ & $\begin{array}{c}\text { Turvinho } \\
(n=5)\end{array}$ & $\begin{array}{l}\text { Zizo } \\
(n=9)\end{array}$ & Motivo da escolha \\
\hline Paca & 20 & 40 & 100 & "sabor e maciez da carne" \\
\hline Veado & - & 20 & 40 & $\begin{array}{l}\text { "a corrida do veado é muito emocionante } \\
\text { (caçada com cães) e o sabor da carne" }\end{array}$ \\
\hline Porco-do-mato & - & 40 & 20 & "pela carne boa e pela grande quantidade" \\
\hline Anta & - & - & 20 & "tem bastante carne e pouca gordura" \\
\hline
\end{tabular}

Nota: Correspondência entre o nome popular e científico dos animais citados: Paca (Agouti paca), Veado (Mazama spp.), Anta (Tapirus terrestris) e Porco-do-mato (Tayassu pecari e Pecari tajacu).

Tabela 5. Percentual de mamíferos citados como mais numerosos nas áreas estudadas pelos entrevistados ( $\mathrm{n}=$ número de entrevistas $)$

\begin{tabular}{lcccc}
\hline Espécie & Sede (n=5) & Turvinho (n=5) & Zizo (n=9) & Total (n=19) \\
\hline Anta & 60 & 80 & 40 & 42 \\
Veado & 40 & 20 & 20 & 19 \\
Paca & - & - & 20 & 15 \\
Lebre & 40 & - & 10 & 8 \\
Capivara & - & 20 & 10 & 8 \\
Coati & 20 & - & - & 4 \\
Lontra & 20 & - & - & 4 \\
\hline
\end{tabular}

Nota: Correspondência entre o nome popular e científico dos animais citados: Anta (Tapirus terrestris), veado (Mazama spp.), Lebre (Lepus europaeus), Paca (Agouti paca), Lontra (Lontra longicaudis), Coati (Nasua nasua) e Capivara (Hidrochoerus hydrochaeris). 


\subsubsection{Perfil da caça no entorno do Parque Estadual Carlos Botelho}

Os animais mais caçados atualmente, segundo os moradores, são a paca, tatu, porco-do-mato, macaco-prego, jacutinga, jacu, nambu, juriti e teiú. Os entrevistados das áreas estudadas relacionam o aumento no número de antas devido à restrição da caça na região, mencionando que antigamente era preciso caminhar de 3 a 4 horas na floresta para começar a encontrar pegadas de anta e que hoje elas estão em todo lugar. Um dos entrevistados relata que antigamente se encontravam bandos de até dez jacutingas e hoje, por causa da caça, se encontra apenas um indivíduo ou no máximo dois. Outro entrevistado, que caçou intensivamente na região durante 1961 a 1997, estima que os porcos-do-mato tenham diminuído em torno de 70\% nesses últimos 30 anos.

O Parque Estadual Carlos Botelho foi criado há 22 anos e a maioria dos entrevistados da região da Sede reside na região há menos de 15 anos. Eles afirmam conhecer as restrições de uso na área do Parque e no entorno, todos relataram que não é permitido atividades de caça e extração vegetal em suas propriedades. Porém alguns entrevistados afirmaram conhecer pessoas e até já ter presenciado estas atividades realizadas tanto na área do Parque como em suas propriedades.

A maioria dos entrevistados da área da Base Turvinho afirma já ter caçado antigamente, e que hoje não caçam mais devido a restrições de uso impostas pela lei e por medo da fiscalização no entorno do Parque. Porém durante minha residência de sete meses neste local durante este estudo, percebi que alguns dos entrevistados ainda caçam esporadicamente. Dois dos entrevistados passaram metade de suas vidas morando na região se alimentando de carne de caça e palmito. Estes contribuíram com ricas informações sobre técnicas de caçadas, comportamento de animais silvestres e informações sobre a flora, principalmente de árvores (fruteiras) preferidas pelos animais, bem como suas épocas de frutificação.

Todos os entrevistados da região da Sede consideram que a fiscalização de rotina do PECB é eficiente e afasta os palmiteiros e caçadores da área, porém citaram que às vezes pescadores invadem os açudes das fazendas e quando a fiscalização aparece, eles “correm para o mato". Segundo os entrevistados, os palmiteiros atuam mais nas áreas 
afastadas do Parque, pois a polícia ambiental está sempre presente na sede do parque, próximo às propriedades do entorno onde foram realizadas as entrevistas, e porque existem também as rondas internas feitas pelos próprios funcionários das propriedades, que denunciam os infratores para a polícia.

Nas instalações da Base Turvinho reside apenas à família de um funcionário do PECB, que fiscaliza as trilhas da região, a procura de indícios de caçadores e palmiteiros, relatando-os, através de rádio, para a equipe de fiscalização na Sede do Parque. Este funcionário já sofreu ameaças de morte de palmiteiros de outras localidades que atuam na região e relatou que, como é o único funcionário encarregado de fiscalizar a região, as áreas mais afastadas da Base Turvinho ficam difíceis de ser frequentemente vistoriadas devido à distância.

A maioria dos entrevistados (4) afirma que a fiscalização que atua na região do Turvinho não afasta os palmiteiros e caçadores, apenas um entrevistado acredita que a fiscalização evita as atividades extrativistas ilegais na área. Isto é bem expresso em alguns relatos dos entrevistados em relação à fiscalização da polícia ambiental e dos funcionários do PECB na Base Turvinho:

"A fiscalização afasta no momento, depois os palmiteiros voltam entrando por outros cantos do sertão. Tem bastante trilhas de burros no mato" (morador do entorno da Base Turvinho).

"Não afasta, os palmiteiros sempre aparecem no meu portão, eles são mais espertos que a polícia. Na represa aparecem muitos pescadores ilegais, que complica a vida dos funcionários do sítio" (morador do entorno da Represa São José).

“Os palmiteiros não acabam, a polícia não vence" (morador do Bairro Turvinho).

Neste conflito entre os extrativistas ilegais (palmiteiros) e os funcionários da fiscalização do PECB, ocorreu o assassinato do vigia Marco Antônio dos Santos Costa, o "Marquinho", em 13 de março de 1998, fato este que marcou o programa de 
fiscalização desta unidade de conservação. Durante realização de ronda de rotina, ele foi atingido por um grupo de palmiteiros próximo ao Rio Quilombo, junto ao bairro Saibadela e ao Parque Estadual Intervales (Ferraz \& Varjabedian, 1999).

\subsubsection{Perfil da caça na região do Parque do Zizo}

Os caçadores distinguem duas categorias de caça: caça de subsistência e predatória, e consideram a primeira como legítima e de baixo impacto segundo seus próprios relatos:

"A caça predatória é aqueles que chegam no Sertão com jipe e com muitos cachorros, aqueles que caçam para comer não prejudicam a natureza" (morador do entorno do Parque do Zizo).

“Quem caça por esporte, só para matar não tá com nada, quem não mora no mato não pode sair atirando em tudo que vê, quem mora no mato depende da carne para fazer uma misturinha, eu acho que não tem problema, pois ele depende do bicho" (caçador).

"Deus me livre matar uma onça, tem que matar o bicho que cria bastante, que é mais abundante, não pode matar uma anta que cria uma vez por ano" (caçador).

A caça de subsistência sempre foi praticada pelos moradores vizinhos do "sertão" região que hoje é o Parque do Zizo até o encontro com o Parque Estadual Carlos Botelho que é chamado pela população como "reserva". Nas entrevistas com a população do entorno das áreas estudadas, o local citado como melhor área para caçar é a região do Rio Pedro Vaz (atual Parque do Zizo e entorno) e no Ribeirão Grande (Parque Estadual Carlos Botelho - Base Turvinho e Sede), pois nestes locais os animais são mais abundantes e quase não há fiscalização, segundo os entrevistados. No entorno do Parque do Zizo um dos entrevistados e seu filho foram presos durante vinte dias por possuir espingardas sem documentação, que foram apreendidas pela polícia militar de São 
Miguel Arcanjo. Ao ser entrevistado, relatou que não caça mais, pois a polícia levou suas armas.

O entorno das áreas protegidas desta região é pouco habitado, não há muitas residências e por muito tempo foi um lugar onde caçadores da região e de outras cidades, aproveitaram para caçar e cortar o palmito juçara (Euterpe edulis), sem problemas com a lei, pois não havia fiscalização até poucos anos atrás. Atualmente as quadrilhas de palmiteiros continuam explorando o palmito ainda existente na região. Ao caminhar nas trilhas abertas por eles, notei muitas pegadas de burros, utilizados para transportar o palmito. Como o palmito está se tornando escasso fora das áreas protegidas, os palmiteiros entram ilegalmente no Parque do Zizo e Parque Estadual Carlos Botelho, que ainda possuem grandes estoques destas palmeiras.

O corte de palmito varia de plantas muito jovens até árvores adultas. Porém em algumas áreas os palmiteiros estão no estágio de "recorte", (cortando árvores jovens) o que pode causar prejuízo na estrutura da população da espécie no local.

Os caçadores e palmiteiros circulam no Parque do Zizo onde começa o "sertão", e em todo o contínuo de mata que se estende até o PECB. (Figura 1) Nesta área de aproximadamente 20.000 ha entre os parques existem grandes propriedades particulares, onde não há fiscalização, somente caseiros que não conseguem percorrer extensas áreas de floresta de terreno acidentado. Estes moradores não conseguem evitar a atuação destas quadrilhas de palmiteiros e caçadores. Alguns moradores relataram receberem inúmeras ameaças de morte feitas por essas pessoas, se eles denunciarem algo para polícia.

A Polícia Florestal de Itapetininga fiscaliza esporadicamente a região, mas devido ao difícil acesso, não consegue flagrar os caçadores e palmiteiros, que conhecem bastante o local. Ainda assim, me parece que, os esforços dos policiais estão mostrando resultado positivo, pois os entrevistados relatam que a caça e a extração de palmito está diminuindo neste local, decorrente das visitas periódicas da polícia ambiental, que faz a patrulha em todo o entorno do PECB. Nas regiões mais afastadas, e nas grandes propriedades particulares, entretanto, as atividades ilegais continuam ocorrendo, devido à falta de patrulha da polícia e funcionários da equipe de fiscalização do PECB. 
A criação da Reserva Particular Parque do Zizo teve efeitos nas práticas de caça da população na região. Com a instalação do portão de entrada do parque ficou explícita a necessidade de autorização para passagem. Com isto pode-se certamente bloquear a entrada de carros no local e diminuir o trânsito de pessoas, porém a entrada de caçadores e palmiteiros será restrita somente com a fiscalização eficiente no interior e nas divisas do parque. Nas entrevistas, a reação das pessoas foi positiva sobre a criação do Parque do Zizo, mesmo sabendo que não poderiam mais caçar e cortar o palmito, como mostra os relatos dos entrevistados:

"Acho importante, é um lugar destes que a gente precisava ter para adiantar a região, como a gente já conhece a região a tempo" (morador do entorno do Parque do Zizo).

"Sempre é bom que tenha alguém com a mentalidade da preservação, o pessoal do parque teve uma iniciativa louvável” (morador do entorno do Parque do Zizo).

\subsubsection{Técnicas de caça utilizadas pelos moradores da região}

A caçadas foram relatadas por alguns entrevistados $(n=5)$, não se registrou a prática em nenhuma vez pelo sexo feminino. Foram registradas quatro técnicas de caça: a ponto ou esbarro, espera, com cães e com armadilha (descrição completa em Sanchez, 1997).

As armas utilizadas para todas as técnicas foram espingardas cartucheiras, de calibre variando entre 20 a 32. Um dos entrevistados mostrou os cartuchos preparados por ele mesmo, os outros compram munição pronta. Três dos entrevistados relataram que quando caçavam utilizavam sempre a caçada com cães. Os caçadores entrevistados e observados diretamente saem para caçadas com facão, espingarda, mochilas feitas de sacos de estopa e um saco de sal para temperar a caça quando pernoitam no mato. $\mathrm{Na}$ área existem vários ranchos feitos de madeira cobertos com lonas, construídos pelos caçadores e palmiteiros, para uso nos períodos que ficam na mata (Figura 5). Todos os 
barracos observados eram feitos com taquara (bambu) e o caule de palmitos jovens cortados.

Na região da Base Turvinho encontrei diversas trilhas feitas por caçadores na beira da represa com a presença de armadilhas para capturar paca. Estas armadilhas são do tipo "chiqueiro", onde o caçador coloca uma ceva, em geral milho, para atrair o animal para dentro de um cercado feito com gravetos, posicionados na mira de um canhãozinho (pequena espingarda amarrada por um fio preso no centro do chiqueiro). Quando o animal esbarra no fio aciona o gatilho, que dispara um tiro na altura do animal. Este sistema é montado apenas quando o caçador está presente no local, onde permanece escondido esperando o som do disparo para então verificar o animal abatido (Figura 6).

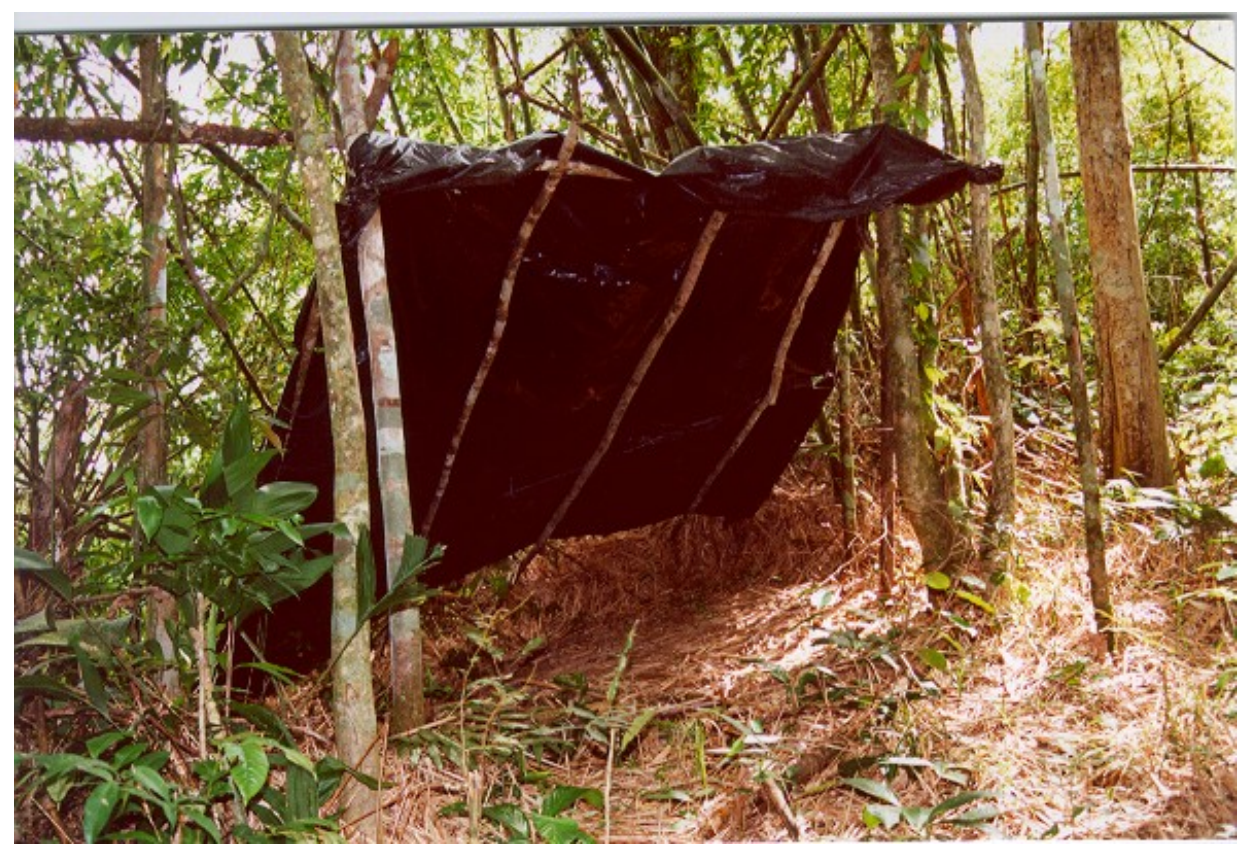

Figura 5 - Acampamentos de palmiteiros e caçadores encontrados no Parque do Zizo 


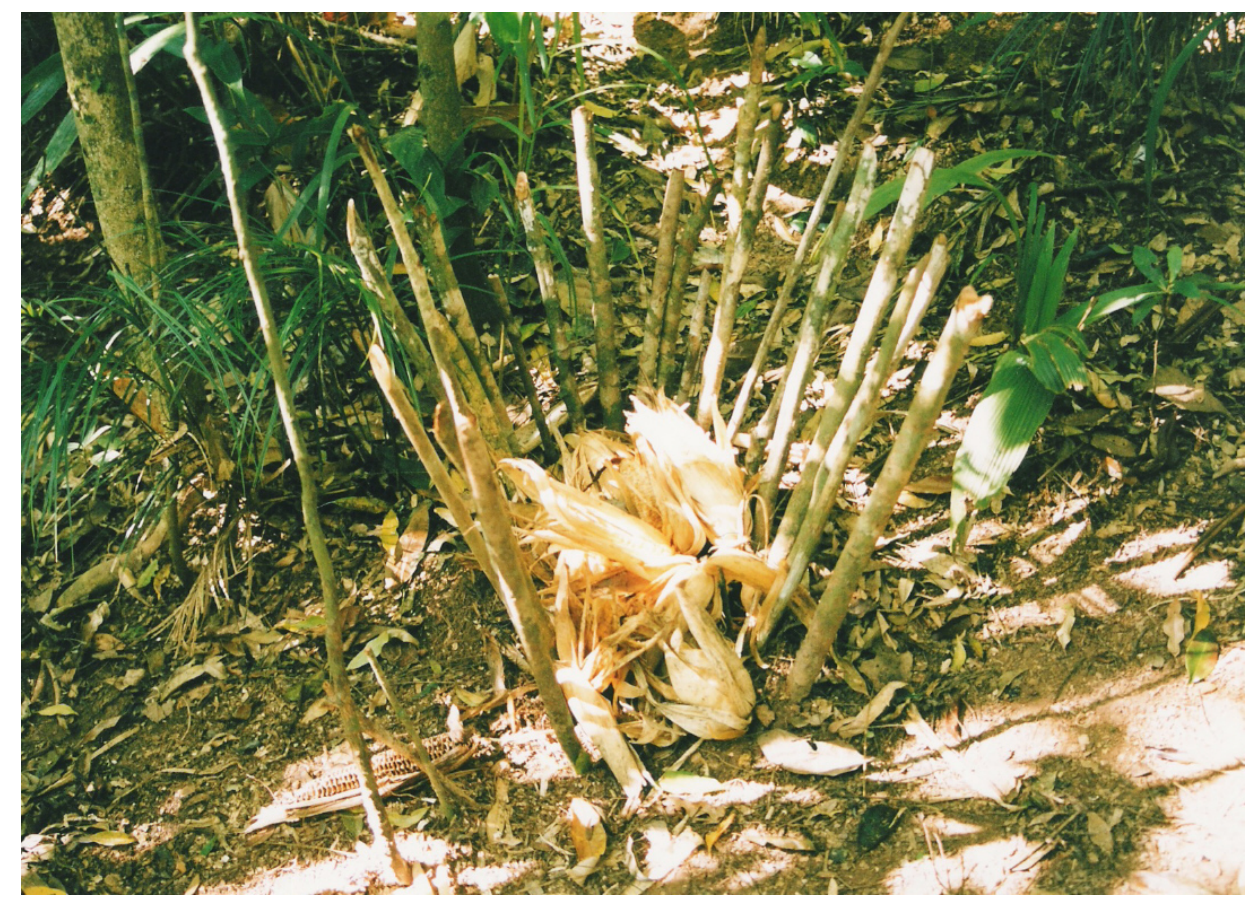

Figura 6 - Armadilha do tipo "chiqueiro" com ceva de milho para captura de paca (Agouti paca) encontrada na Base Turvinho

\subsection{Registros da freqüência de uso de recursos naturais por populações humanas, segundo os relatórios da equipe de fiscalização do Parque Estadual Carlos Botelho.}

Segundo os relatórios da equipe de fiscalização do PECB, no período de 2000 a 2003, foram realizadas 38 visitas (rondas) no entorno do Parque do Zizo, porém a região da sede deste Parque, onde se concentram as trilhas utilizadas neste estudo, foi visitada apenas seis vezes. Na região da Base Turvinho foram feitas 55 rondas, inclusive em algumas das trilhas utilizadas neste estudo. Na região da Sede (PECB), próximo às trilhas utilizadas no estudo, não constam registros de denúncias e evidências de atividades de caça e extração de palmito nos relatórios da fiscalização. As rondas feitas pela equipe de físcalização estão, na maioria das vezes, relacionadas ao atendimento de denúncias feitas pela população local, o que significa que as áreas não são fiscalizadas com a mesma freqüência. Além disto, as rondas são programadas pela administração do 
PECB, em função de seu conhecimento das áreas com mais ocorrências recentes. Assim, o número de rondas já é um indicativo de pressão de caça e extrativismo em cada área.

\subsubsection{Extrativismo vegetal}

No Parque Estadual Carlos Botelho e entorno, no período de 2000 a 2003, foram apreendidas 26.724 unidades de palmito. No ano de 2000 foram apreendidas 4.783 , em 2001 foram 9.060, em 2002 foram 3.444 e em 2003, ano com maior número de apreensões, foram 9.482 unidades de palmito, principalmente na região do núcleo Sete Barras.

Os dados de vestígios de extrativismo vegetal de palmito estão relacionados ao encontro de utensílios para extração, processamento e transporte (Tabela 6). Como facões, machados, panelas para o cozimento, vidros para o envasamento, barcos e carros para o transporte do palmito. Os animais de carga, burros e mulas, são utilizados para transportar os palmitos das áreas afastadas da floresta. Foram encontradas muitas armas, na maioria espingardas.

Tabela 6. Registros de evidências e vestígios de extração ilegal de palmito (Euterpe edulis) no Parque do Zizo e entorno, segundo os relatórios da fiscalização do PECB

\begin{tabular}{lccccc}
\hline Evidências/Ano & $\mathbf{2 0 0 0}$ & $\mathbf{2 0 0 1}$ & $\mathbf{2 0 0 2}$ & $\mathbf{2 0 0 3}$ & Total \\
\hline Palmitos apreendidos & 2077 & 2355 & 141 & 0 & 4573 \\
Barracos & 2 & 0 & 0 & 0 & 2 \\
Animais de carga & 17 & 0 & 0 & 0 & 17 \\
Vestígios & 15 & 18 & 9 & 1 & 43 \\
Denúncias & 1 & 0 & 0 & 0 & 1 \\
Total de ocorrências & 9 & 10 & 12 & 1 & 32 \\
\hline
\end{tabular}


Tabela 7. Registros de evidências e vestígios de extração ilegal de palmito (Euterpe edulis) na Base Turvinho e entorno, segundo os relatórios da fiscalização do PECB

\begin{tabular}{lccccc}
\hline Evidências/Ano & $\mathbf{2 0 0 0}$ & $\mathbf{2 0 0 1}$ & $\mathbf{2 0 0 2}$ & $\mathbf{2 0 0 3}$ & Total \\
\hline Palmitos apreendidos & 253 & 1505 & 846 & 227 & 2831 \\
Barracos & 1 & 9 & 0 & 3 & 13 \\
Animais de carga & 0 & 31 & 0 & 4 & 35 \\
Vestígios & 5 & 12 & 6 & 5 & 1 \\
Denúncias & 0 & 1 & 0 & 3 & 4 \\
Total de ocorrências & 4 & 14 & 6 & 9 & 33 \\
\hline
\end{tabular}

Os resultados das apreensões de palmitos indicam que a região do Parque do Zizo foi mais visada pelos palmiteiros do que a região da Base Turvinho. Foram apreendidos duas vezes mais palmitos na região do Parque do Zizo (Tabela 6), mesmo com menos rondas. Nos dois locais foram encontrados animais de carga, como burros, utilizados para carregar os palmitos do interior da mata para as estradas.

$\mathrm{Na}$ região da Base Turvinho foram registrados mais barracos de madeira, utilizados pelos palmiteiros e caçadores para pernoitarem na mata (Tabela 7) do que na região do Parque do Zizo. Como a principal atividade de subsistência da população do entorno da região da Base Turvinho, não é a extração de palmito (entrevistas), esta grande quantidade de barracos de madeira pode ser explicada pela invasão de grupos de extrativistas ilegais advindos de outras localidades.

\subsubsection{Atividades de caça}

Durante o período de 2000 a 2003, somente dois caçadores foram presos em flagrante no entorno do Parque do Zizo, no Rio Baú. Foram apreendidas duas espingardas e uma irara (Eira barbara) abatida por eles. As ocorrências foram sempre registradas através de vestígios, como penas e pêlos encontrados nos barracos, cevas, 
armadilhas, canhãozinhos, estilingues, espingardas, além das denúncias das atividades de caça feitas pela população (Tabela 8). As espécies caçadas registradas nos relatórios foram a anta (Tapirus terrestris), capivaras (Hidrochoerus hydrochaeris), tatus (não identificado), Pássaros (diversas espécies, não identificadas) e porcos-do-mato (não identificado).

Tabela 8. Registros de evidências e vestígios de atividades de caça no Parque do Zizo e entorno, segundo os relatórios da fiscalização do PECB

\begin{tabular}{lccccc}
\hline Evidências/Ano & $\mathbf{2 0 0 0}$ & $\mathbf{2 0 0 1}$ & $\mathbf{2 0 0 2}$ & $\mathbf{2 0 0 3}$ & Total \\
\hline Animais registrados & 1 & 3 & 0 & 0 & 4 \\
Barracos & 0 & 1 & 0 & 0 & 1 \\
Vestígios & 1 & 4 & 1 & 0 & 6 \\
Denúncias & 0 & 0 & 0 & 0 & 0 \\
Total de ocorrências & 2 & 3 & 1 & 0 & 6 \\
\hline
\end{tabular}

Tabela 9. Registros de evidências e vestígios de atividades de caça na Base Turvinho e entorno, segundo os relatórios da fiscalização do PECB

\begin{tabular}{lccccc}
\hline Evidências/Ano & $\mathbf{2 0 0 0}$ & $\mathbf{2 0 0 1}$ & $\mathbf{2 0 0 2}$ & $\mathbf{2 0 0 3}$ & Total \\
\hline Animais registrados & 2 & 2 & 0 & 1 & 5 \\
Barracos & 0 & 0 & 0 & 0 & 0 \\
Vestígios & 3 & 3 & 4 & 2 & 12 \\
Denúncias & 2 & 0 & 0 & 2 & 4 \\
Total de ocorrências & 6 & 3 & 4 & 3 & 16 \\
\hline
\end{tabular}

A maior freqüência de registro de atividades de caça foi na área do Turvinho (Tabela 9), devido à sua proximidade com a Represa São José, é comum à presença de pescadores, caçadores e palmiteiros nas trilhas da Base Turvinho, aproveitando à 
dificuldade da fiscalização nas margens da represa. O Rio Curupira deságua na represa, formando o braço do Curupira, local bastante freqüentado pelos pescadores, caçadores e palmiteiros, é comum observar barcos na represa geralmente de caçadores de capivara.

Sintetizando todas as informações sobre atividades de caça e extrativismo vegetal nas áreas estudadas (Tabela 10), nota-se que a Sede é o local com menor presença humana e pressão antrópica. Já no Turvinho, mesmo com a presença da fiscalização, ocorreram caça e extração vegetal, os registros de atividades de caça representaram $29,1 \%$ e o extrativismo vegetal $60 \%$ do total de visitas na área pela fiscalização no período de 2000 a 2003. No Zizo os registros de atividades de caça representaram 15,7\% e extrativismo vegetal $76,4 \%$. A fiscalização registrou que o maior impacto humano sofrido nas duas áreas é o extrativismo vegetal de palmito e que no Zizo este impacto foi maior que na área do Turvinho. Com a caça ocorreu o inverso, o Turvinho apresentou mais registros que a região do Zizo, considerada o "sertão dos caçadores". Porém, o número de denúncias foi maior no Turvinho do que no Zizo no ano de 2003 e, consequentemente, o número de rondas também, o que pode mascarar os resultados de pressões antrópicas na área do Zizo. Entretanto, as observações diretas de atividades de caça nas duas áreas também indicaram que o Zizo, no período de Janeiro a Agosto de 2003, sofre uma pressão de caça menor que o Turvinho.

Tabela 10. Síntese dos registros de atividades de caça na região das áreas estudadas, segundo as observações diretas de janeiro a agosto de 2003 e os relatórios da fiscalização (2000 a 2003)

\begin{tabular}{lccc}
\hline Evidência/Área & Sede & Zizo & Turvinho \\
\hline Observações diretas & 0 & 6 & 11 \\
Ocorrências de caça (fiscalização) & 0 & $6(0)$ & $16(3)$ \\
Número total de visitas (rondas) & $1(0)^{1}$ & $38(1)$ & $55(14)$ \\
Categoria de pressão de caça & Ausente & Moderado & Moderado \\
\hline
\end{tabular}

${ }^{1}$ (Dados dos relatórios no período de janeiro a setembro de 2003) 


\subsection{Levantamento de espécies de mamíferos de médio e grande porte através de parcelas de areia}

Através do método de registro de pegadas em parcelas de areia foram registradas 15 espécies (Tabela 11), das quais uma é doméstica (Canis familiaris), e as demais mamíferos silvestres de médio e grande porte. Neste estudo a espécie de marsupial Didelphis aurita (gambá) foi considerada de médio porte, pois possui o tamanho corporal e área de vida muito maior que as espécies de pequenos mamíferos (Pardini, 2001), além de ser uma espécie caçada na região pelos moradores do entorno do Parque do Zizo (relatos nas entrevistas). Na Sede e Turvinho foram registradas 11 espécies e no Zizo registraram-se 10 espécies. As espécies Puma concolor (onça-parda), Tamandua tetradactyla (tamanduá-mirim) e Conepatus chinga (zorrilho) foram registradas somente na Sede, Dasyprocta azarae (cutia) no Turvinho e Eira barbara (irara) no Zizo. A espécie Canis familiaris (cão doméstico) foi registrada apenas no Turvinho, provavelmente porque neste local as residências estão mais próximas à borda da mata e consequentemente das trilhas utilizadas no estudo. Esta espécie não foi analisada juntamente com as espécies silvestres, pois seus registros foram utilizados como evidências de atividades de caça.

A riqueza de espécies foi heterogênea entre as trilhas (Figura 8). Porém não foi possível detectar diferenças significativas na riqueza total das espécies, como extinções de espécies devido às pressões antrópicas nas áreas estudadas. Contudo, entre as sessões de vistoria as diferenças na riqueza média ocorreram entre a Sede $(X=1,66 ; S=0,57)$ com maior riqueza, e o Zizo $(X=0,33 ; S=0,57)$ com menor riqueza na sessão 1 . $O$ número de espécies aumentou na sessão 2 , e nesta época o Turvinho $(X=5 ; S=1)$ apresentou o maior número de espécies. Na sessão 3 o Turvinho $(X=5,6 ; S=0,57)$ também apresentou a maior média de riqueza, seguido da Sede $(X=4 ; S=4,7)$ e Zizo $(X=0,33 ; S=0,57)$. 
Tabela 11. Espécies, características ecológicas e de uso de mamíferos de médio e grande porte registrados nas parcelas de das áreas estudadas

\begin{tabular}{lllccc}
\hline Espécie & Nome popular & Dieta ${ }^{\mathbf{1}}$ & $\begin{array}{c}\text { Massa } \\
(\mathbf{k g})^{\mathbf{1}}\end{array}$ & Tamanho & Cinegético \\
\hline Tapirus terrestris & Anta & herbívoro & 239 & Grande & $\mathrm{X}$ \\
Puma concolor & Onça-Parda & carnívoro & 74,5 & Grande & \\
Mazama americana & Veado -mateiro & herbívoro & 29 & Grande & $\mathrm{X}$ \\
Leopardus pardalis & Jaguatirica & carnívoro & 10 & Médio & \\
Agouti paca & Paca & herbívoro & 8,23 & Médio & $\mathrm{X}$ \\
Cerdocyon thous & Cachorro-do-mato & onívoro & 6,5 & Médio & \\
Procyon cancrivorus & Guaxinin & onívoro & 5,4 & Médio & \\
Tamadua tetradactyla & Tamanduá-mirim & mirmecófago & 5,2 & Médio & \\
Nasua nasua & Coati & onívoro & 5,1 & Médio & $\mathrm{X}$ \\
Eira barbara & Irara & carnívoro & 4,8 & Médio & \\
Dasypus novencinctus & Tatu-galinha & onívoro & 3,65 & Médio & $\mathrm{X}$ \\
Dasyprocta azarae & Cutia & herbívoro & 2,8 & Médio & $\mathrm{X}$ \\
Leopardus spp. & Gato-do-mato & carnívoro & 2,25 & Médio & \\
Conepatus chinga & Zorrilho & onívoro & 1,75 & Médio & \\
Didelphis aurita & Gambá & onívoro & 1 & Médio & $\mathrm{X}$ \\
\hline
\end{tabular}

${ }^{1}$ Fonseca et al., 1996

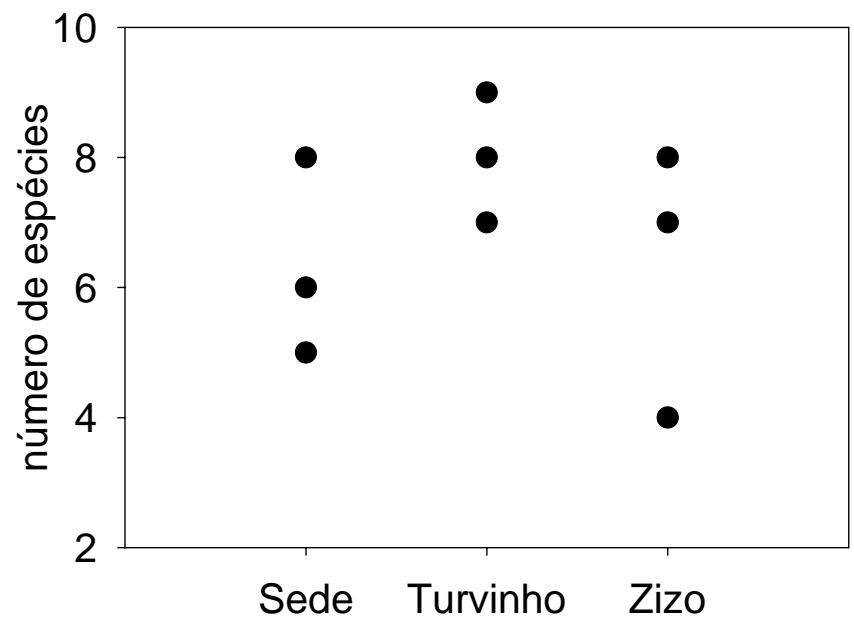

Figura 7 - Riqueza de espécies de médios e grandes mamíferos nas trilhas das áreas 


\section{$3.5 \mathrm{O}$ uso de diferentes tipos de registro em parcelas de areia}

Durante o período de estudo de janeiro a agosto de 2003 foram obtidos 1.420 registros de pegadas em parcelas, 542 registros de passagem, 426 registros de presença na parcela e 132 registros de presença nas trilhas das três áreas estudadas. Todos os tipos de registro apresentaram uma forte associação entre si (Figura 8).

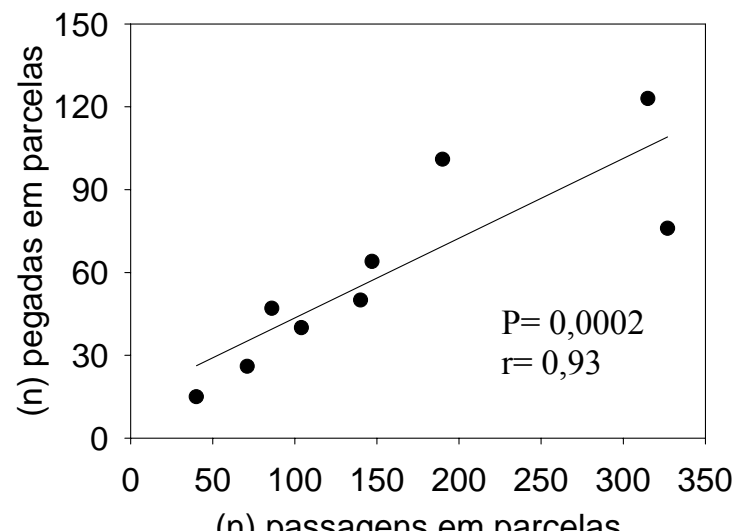

(n) passagens em parcelas

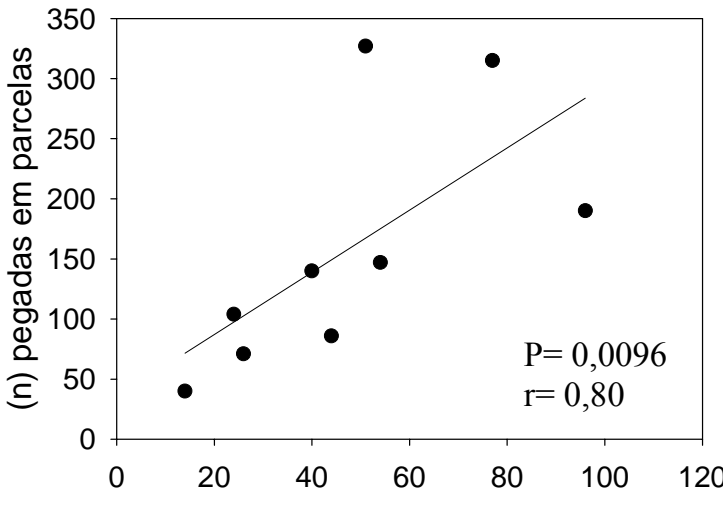

(n) parcelas com pegadas
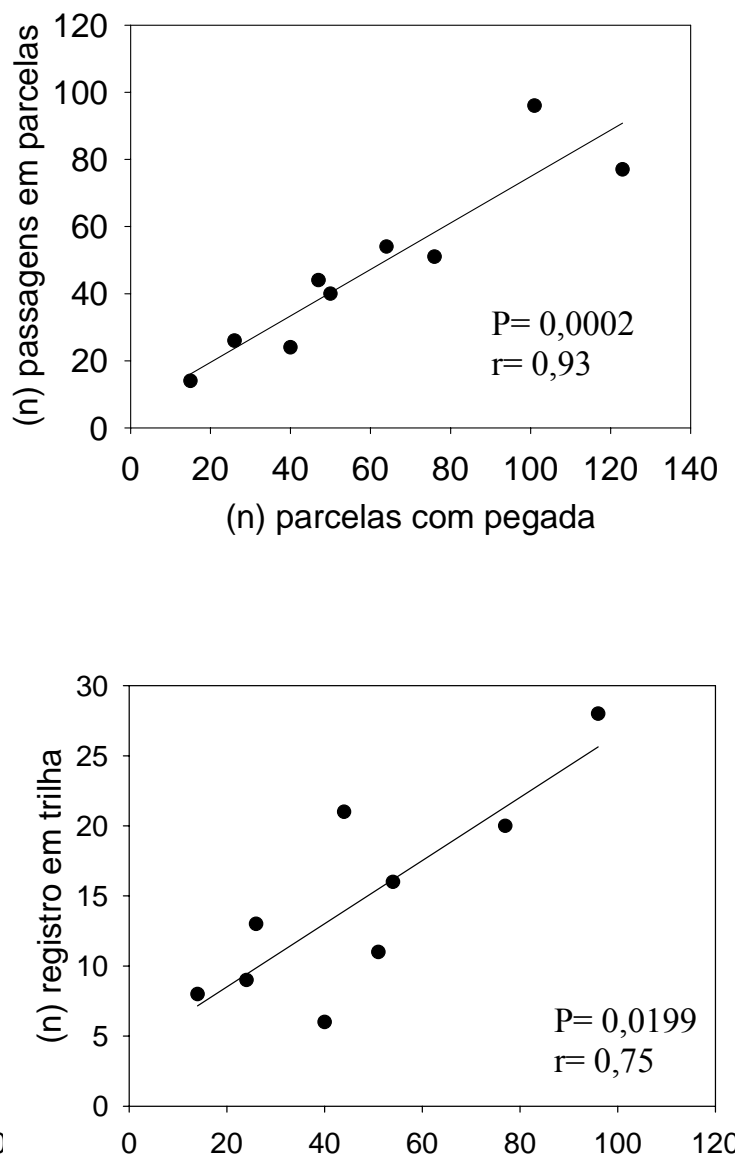

(n) parcelas com pegadas

Figura 8 - Correlação entre os diferentes tipos de registros em parcelas de areia. Cada ponto representa o número total de registros de cada réplica (trilha) das três áreas estudadas. $\mathrm{r}=$ Coeficiente de correlação de Spearman, $\mathrm{P}=$ probabilidade associada a este coeficiente, $\alpha=0,05$ (Bioestat 3.0) 


\subsection{Comparação da freqüência de ocorrência de mamíferos de médio e grande porte entre as áreas estudadas}

As comparações foram feitas utilizando apenas dois tipos de registro, presença na parcela e presença na trilha (Tabela 12 e 13), considerados os que menos apresentam independência nos registros entre parcelas, devido aos fatores ecológicos e biológicos das espécies de mamíferos.

As áreas não apresentaram diferenças significativas quanto a número total registros de presença na parcela $(H=1,68$, g.l. $=2 ; \mathrm{p}>0,05)$ e presença na trilha $(\mathrm{H}=3,28$, g.l. $=2 ; p>0,05)$ dos mamíferos estudados. Entretanto, a Sede e o Turvinho que possuem fiscalização, apresentam duas vezes mais registros do que o Zizo que não possui físcalização.

Somente 10 espécies de mamíferos de médio e grande porte tiveram um número de registros nas parcelas suficientes para a análise entre as áreas estudadas. Destas, a paca (Agouti paca) foi a única espécie com um número de ocorrências diferente entre as áreas $(\mathrm{H}=6,00$, g.1. $=2 ; \mathrm{p}<0,05)$, com 14 ocorrências no Turvinho, 4 no Zizo e 1 na Sede (Tabela 13). O Turvinho também apresentou a maior freqüência de caça, segundo os relatórios da fiscalização, e desta espécie segundo as entrevistas com população local e observações diretas de armadilhas e puleiros com ceva, específicos para capturar paca. Contudo, a alta freqüência desta espécie nas trilhas do Turvinho pode estar relacionada a recolonização por outros indivíduos para ocupar os territórios deixados pelos indivíduos caçados. 
Tabela 12. Número de registros da presença de cada espécie nas parcelas de areia, em cada trilha e total por área de estudo. As últimas duas colunas indicam o valor do teste de Kruskal Wallis $(\mathrm{H})$ e probabilidade associada ao teste $(\mathrm{P}), \alpha=0,05$

\begin{tabular}{|c|c|c|c|c|c|c|c|c|c|c|c|c|c|c|c|}
\hline \multirow{2}{*}{ Espécie } & \multicolumn{3}{|c|}{ Sede } & \multirow[b]{2}{*}{ total } & \multicolumn{3}{|c|}{ Base Turvinho } & \multirow[b]{2}{*}{ total } & \multicolumn{3}{|c|}{ Parque do Zizo } & \multirow[b]{2}{*}{ total } & \multirow{2}{*}{ Total } & \multirow{2}{*}{$\mathbf{H}$} & \multirow{2}{*}{$\mathbf{p}$} \\
\hline & S1 & $\mathrm{S} 2$ & S3 & & $\mathrm{T} 1$ & $\mathrm{~T} 2$ & T3 & & $\mathrm{Z1}$ & $\mathrm{Z2}$ & Z3 & & & & \\
\hline Cerdocyon thous & 30 & 40 & 17 & 87 & 0 & 23 & 2 & 25 & 10 & 0 & 0 & 10 & 122 & 4,629 & 0,096 \\
\hline Didelphis spp. & 2 & 16 & 4 & 22 & 18 & 22 & 1 & 41 & 6 & 1 & 6 & 13 & 76 & 4,622 & 0,099 \\
\hline Leopardus spp. & 3 & 6 & 1 & 10 & 2 & 8 & 7 & 17 & 12 & 1 & 1 & 14 & 41 & 0,881 & 0,644 \\
\hline Tapirus terrestris & 0 & 0 & 0 & 0 & 8 & 17 & 1 & 26 & 6 & 2 & 0 & 8 & 34 & 0,628 & 0,731 \\
\hline Agouti paca & 0 & 1 & 0 & 1 & 8 & 17 & 3 & 28 & 2 & 2 & 0 & 4 & 33 & 1,103 & 0,576 \\
\hline Nasua nasua & 7 & 9 & 1 & 17 & 1 & 0 & 4 & 5 & 0 & 0 & 5 & 5 & 27 & 6,006 & 0,050 * \\
\hline Dasypus novencinctus & 7 & 2 & 0 & 9 & 0 & 4 & 6 & 10 & 3 & 0 & 2 & 5 & 24 & 2,891 & 0,236 \\
\hline Leopardus pardalis & 2 & 0 & 0 & 2 & 4 & 1 & 0 & 5 & 13 & 1 & 0 & 14 & 21 & 0,471 & 0,790 \\
\hline Mazama americana & 0 & 0 & 0 & 0 & 0 & 1 & 2 & 3 & 2 & 15 & 0 & 17 & 20 & 2,622 & 0,270 \\
\hline Puma concolor & 0 & 0 & 14 & 14 & 0 & 0 & 0 & 0 & 0 & 0 & 0 & 0 & 14 & 0,600 & 0,740 \\
\hline Procyon cancrivorus & 0 & 1 & 0 & 1 & 3 & 0 & 0 & 3 & 0 & 0 & 0 & 0 & 4 & 0,622 & 0,732 \\
\hline Dasyprocta azarae & 0 & 0 & 0 & 0 & 0 & 3 & 0 & 3 & 0 & 0 & 0 & 0 & 3 & 0,600 & 0,740 \\
\hline Tamadua tetradactyla & 0 & 0 & 3 & 3 & 0 & 0 & 0 & 0 & 0 & 0 & 0 & 0 & 3 & 0,600 & 0,740 \\
\hline Conepatus chinga & 0 & 2 & 0 & 2 & 0 & 0 & 0 & 0 & 0 & 0 & 0 & 0 & 2 & 0,600 & 0,740 \\
\hline Eira barbara & 0 & 0 & 0 & 0 & 0 & 0 & 0 & 0 & 0 & 2 & 0 & 2 & 2 & 0,600 & 0,740 \\
\hline Total & 51 & 77 & 40 & 168 & 44 & 96 & 26 & 166 & 54 & 24 & 14 & 92 & 426 & 1,689 & 0,430 \\
\hline
\end{tabular}

${ }^{1}$ S1 = guapeva, S2=Copaúva, S3=Cai-pau, T1=Caçador, T2=Curupira, T3=Preguiça, Z1=Barra, Z2=Ouro-fino e Z3=Jatobá.

* Valor significativo em negrito 
Tabela 13 - Número de registros da presença das espécies nas trilha e total por área de estudo. As últimas duas colunas indicam o valor do teste de Kruskal Wallis $(\mathrm{H})$ e probabilidade associada ao teste $(\mathrm{P}), \alpha=0,05$

\begin{tabular}{|c|c|c|c|c|c|c|c|c|c|c|c|c|c|c|c|}
\hline \multirow{2}{*}{ Espécie } & \multicolumn{3}{|c|}{ Sede } & \multirow[b]{2}{*}{ total } & \multicolumn{3}{|c|}{ Base Turvinho } & \multirow[b]{2}{*}{ total } & \multicolumn{3}{|c|}{ Parque do Zizo } & \multirow[b]{2}{*}{ total } & \multirow{2}{*}{ Total } & \multirow{2}{*}{$\mathbf{H}$} & \multirow{2}{*}{$\mathbf{p}$} \\
\hline & $\mathrm{S} 1$ & S2 & S3 & & T1 & T2 & T3 & & Z1 & Z2 & Z3 & & & & \\
\hline Didelphis spp. & 7 & 1 & 1 & 9 & 5 & 7 & 1 & 13 & 3 & 1 & 4 & 8 & 30 & 0,660 & 0,718 \\
\hline Agouti paca & 1 & 0 & 0 & 1 & 7 & 6 & 1 & 14 & 2 & 2 & 0 & 4 & 19 & 3,819 & 0,148 \\
\hline Leopardus spp. & 2 & 1 & 1 & 4 & 3 & 2 & 3 & 8 & 4 & 1 & 1 & 6 & 18 & 2,543 & 0,280 \\
\hline Nasua nasua & 5 & 3 & 1 & 9 & 0 & 1 & 2 & 3 & 0 & 0 & 1 & 1 & 13 & 3,954 & 0,138 \\
\hline Dasypus novencinctus & 1 & 2 & 0 & 3 & 2 & 0 & 2 & 4 & 3 & 0 & 2 & 5 & 12 & 0,606 & 0,718 \\
\hline Cerdocyon thous & 2 & 3 & 1 & 6 & 3 & 0 & 2 & 5 & 1 & 0 & 0 & 1 & 12 & 3,031 & 0,219 \\
\hline Tapirus terrestris & 0 & 0 & 0 & 0 & 3 & 2 & 1 & 6 & 1 & 1 & 0 & 2 & 8 & 5,540 & 0,062 \\
\hline Leopardus pardalis & 0 & 1 & 0 & 1 & 1 & 2 & 0 & 3 & 1 & 1 & 0 & 2 & 6 & 2,778 & 0,249 \\
\hline Mazama americana & 0 & 0 & 0 & 0 & 1 & 0 & 1 & 2 & 1 & 1 & 0 & 2 & 4 & 1,042 & 0,593 \\
\hline Dasyprocta azarae & 0 & 0 & 0 & 0 & 3 & 0 & 0 & 3 & 0 & 0 & 0 & 0 & 3 & 2,618 & 0,270 \\
\hline Procyon cancrivorus & 1 & 0 & 0 & 1 & 0 & 1 & 0 & 1 & 0 & 0 & 0 & 0 & 2 & 0,605 & 0,739 \\
\hline Eira barbara & 0 & 0 & 0 & 0 & 0 & 0 & 0 & 0 & 0 & 2 & 0 & 2 & 2 & 0,600 & 0,740 \\
\hline Tamadua tetradactyla & 0 & 0 & 1 & 1 & 0 & 0 & 0 & 0 & 0 & 0 & 0 & 0 & 1 & 0,622 & 0,732 \\
\hline Puma concolor & 0 & 0 & 1 & 1 & 0 & 0 & 0 & 0 & 0 & 0 & 0 & 0 & 1 & 0,622 & 0,732 \\
\hline Conepatus chinga & 1 & 0 & 0 & 1 & 0 & 0 & 0 & 0 & 0 & 0 & 0 & 0 & 1 & 0,622 & 0,732 \\
\hline Total & 20 & 11 & 6 & 37 & 28 & 21 & 13 & 62 & 16 & 9 & 8 & 33 & 132 & 3,288 & 0,193 \\
\hline
\end{tabular}

${ }^{1} \mathrm{~S} 1=$ guapeva, S2=Copaúva, S3=Cai-pau, T1=Caçador, T2=Curupira, T3=Preguiça, Z1=Barra, Z2=Ouro-fino e Z3=Jatobá. 
Os resultados dos tipos de registro, presença na parcela e presença na trilha, foram utilizados para analisar a freqüência de ocorrência das espécies nas áreas estudadas. Com o tipo de registro presença na trilha nota-se que o cachorro-do-mato $(n=6)$ e o quati $(n=9)$ foram mais freqüentes nas trilhas da Sede, já a paca $(n=14)$ e a anta $(n=6)$ foram mais freqüentes no Turvinho (Figura 9). O veado foi registrado apenas no Turvinho e no Zizo, e ocorreu com a mesma freqüência nas áreas e entre as trilhas de cada área. O guaxinim ocorreu somente na Sede e Turvinho com a mesma freqüência durante as sessões de vistoria. O restante das espécies não apresentou diferenças evidentes de freqüência entre as áreas estudadas. Considerando todas as espécies, o Turvinho teve uma freqüência de espécies $(n=62)$ utilizando as trilhas, durante as sessões de vistoria, duas vezes maior que a Sede $(n=37)$ e o Zizo $(n=33)$ que tiveram freqüências parecidas.

Com o tipo de registro presença na parcela, os resultados mostram que o cachorro-do-mato $(n=87)$ e o quati $(n=17)$ foram registrados utilizando em maior freqüência as trilhas da Sede, que apresenta uma menor presença humana do que as trilhas do Zizo com constante presença humana. No Turvinho a paca $(n=14)$ foi registrada utilizando as trilhas com a freqüência muito maior do que nas outras áreas que apresentaram freqüências parecidas. O restante das espécies apresentou menor diferença na freqüência nas trilhas entre as áreas estudadas. Considerando todas as espécies as trilhas mais utilizadas foram da Sede $(n=168)$ e Turvinho $(n=166)$, o Zizo apresentou o menor número de registros $(\mathrm{n}=92)$ (Figura 10). 

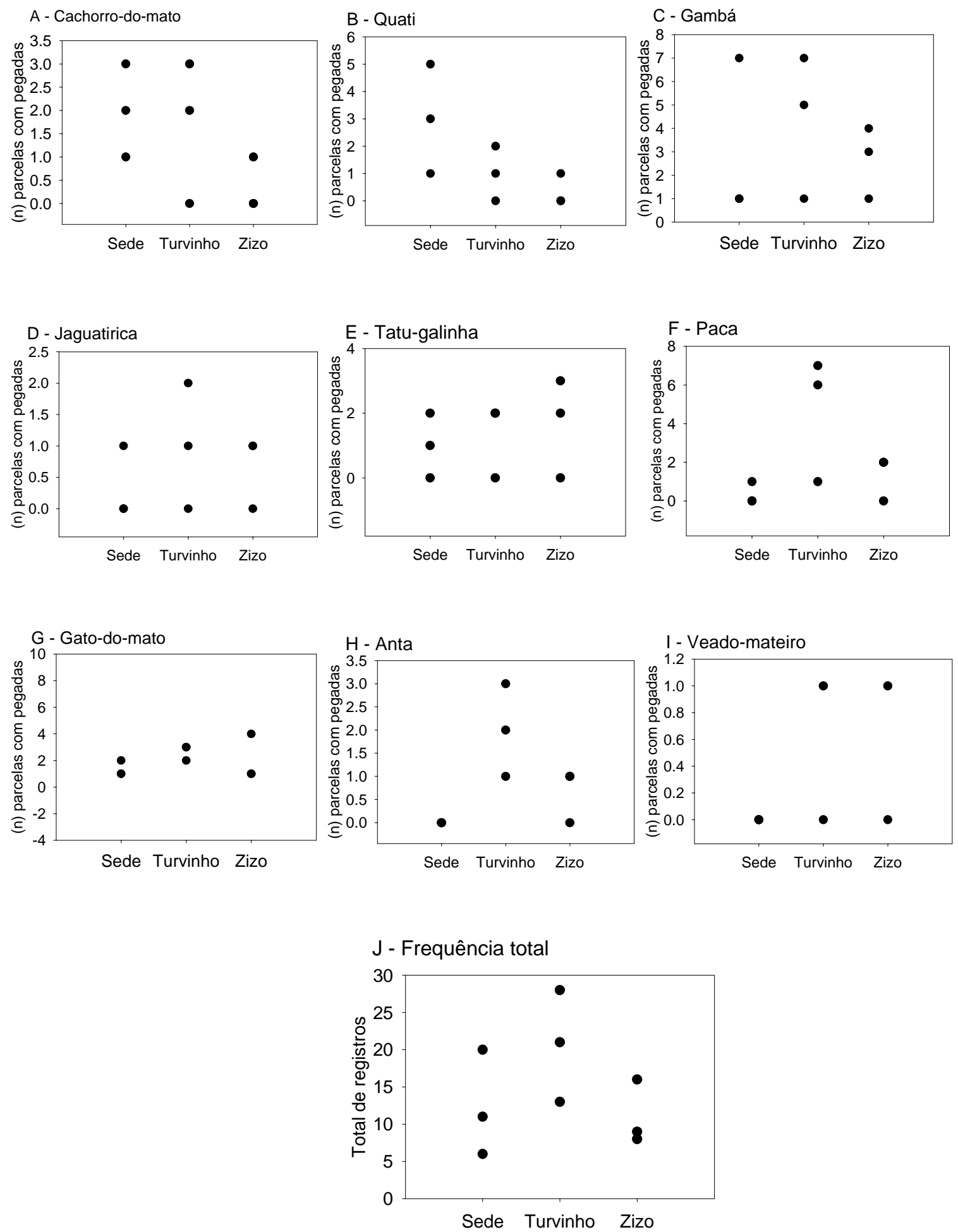

Figura 9 - Freqüência de ocorrência de cada espécie nas trilhas (A - I) e total de espécies $(\mathrm{J})$, utilizando tipo de registro presença na trilha 

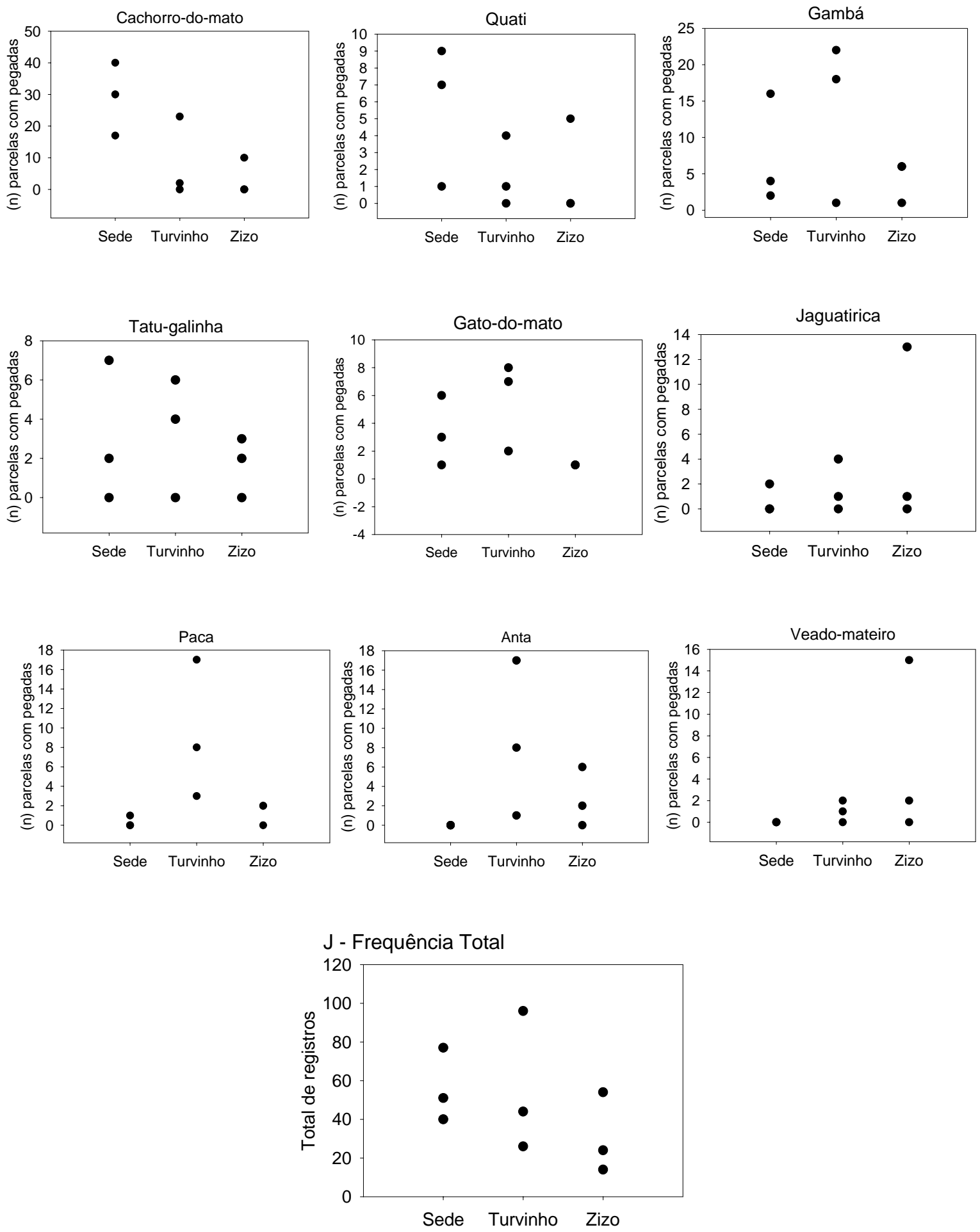

Figura 10 - Freqüência de ocorrência de cada espécie nas trilhas (A - I) e total de espécies (J), utilizando o tipo de registro presença na parcela 


\subsubsection{Espécies agregadas em grupos funcionais (Guildas e Cinegéticos)}

Dentre as espécies separadas em guildas: os carnívoros tiveram a menor freqüência de registros nas parcelas, os herbívoros em relação à freqüência de ocorrência aparecem como um grupo intermediário e os onívoros tiveram o maior número de registros (Tabela 14) entre as guildas. As espécies consideradas cinegéticas (Didelphis aurita, Nasua nasua, Dasyprocta azarae, Agouti paca, Mazama americana, Tapirus terrestris e Dasypus novencinctus) foram mais freqüentes no Turvinho que teve o maior número de registros deste grupo, seguido do Zizo e Sede no tipo de registro presença na trilha. Já no tipo presença na parcela, os onívoros aparecem com o maior número de registros na Sede, seguido do turvinho e Zizo. Os herbívoros tiveram duas vezes mais registros no Turvinho em relação ao Zizo, e na Sede foi obtido apenas um registro, o que não significa a ausência deste grupo na área, este número baixo de registros pode estar relacionado à época de coleta.

Tabela 14. Número de registros totais das espécies de mamíferos de médio e grande porte nas áreas estudadas, separadas em guildas e cinegéticos. As últimas duas colunas indicam o valor do teste de Kruskal Wallis (H) e probabilidade associada ao teste $(\mathrm{P}), \alpha=0,05$

\begin{tabular}{|c|c|c|c|c|c|c|}
\hline Grupos funcionais & Sede & $\begin{array}{c}\text { Área } \\
\text { Turvinho }\end{array}$ & Zizo & Total & $\mathbf{H}$ & $\mathbf{P}$ \\
\hline \multicolumn{7}{|l|}{ Presença na trilha $^{1}$} \\
\hline Cinegéticos & 22 & 45 & 22 & 89 & 3,288 & 0,193 \\
\hline Onívoros & 29 & 26 & 15 & 70 & 2,527 & 0,282 \\
\hline Herbívoros & 1 & 25 & 8 & 34 & 5,581 & 0,061 \\
\hline Carnívoros & 6 & 7 & 10 & 23 & 2,666 & 0,263 \\
\hline \multicolumn{7}{|c|}{ Presença na parcela $^{1}$} \\
\hline Cinegéticos & 49 & 116 & 52 & 217 & 2,489 & 0,288 \\
\hline Onívoros & 138 & 84 & 33 & 255 & 4,497 & 0,109 \\
\hline Herbívoros & 1 & 60 & 29 & 90 & 3,822 & 0,148 \\
\hline Carnívoros & 26 & 22 & 30 & 78 & 0,695 & 0,707 \\
\hline
\end{tabular}

${ }^{1}$ Tipos de registro em parcelas de areia 
Os herbívoros, segundo o tipo de registro presença na trilha, tiveram uma freqüência maior no Turvinho em relação à Sede, e com menor diferença em relação ao Zizo, durante os dias de coleta. Por outro lado, os onívoros tiveram maior freqüência de ocorrência nas trilhas da Sede e do Turvinho em relação ao Zizo. Os carnívoros tiveram o maior número de registros no Zizo, quanto que a Sede e o Turvinho tiveram freqüências parecidas. Já para as espécies cinegéticas a maior freqüência foi registrada no Turvinho, a Sede e o Zizo tiveram freqüências parecidas. Em todos os grupos ocorreram variações de freqüência de ocorrência temporal entre as trilhas de uma mesma área (Figura 11).
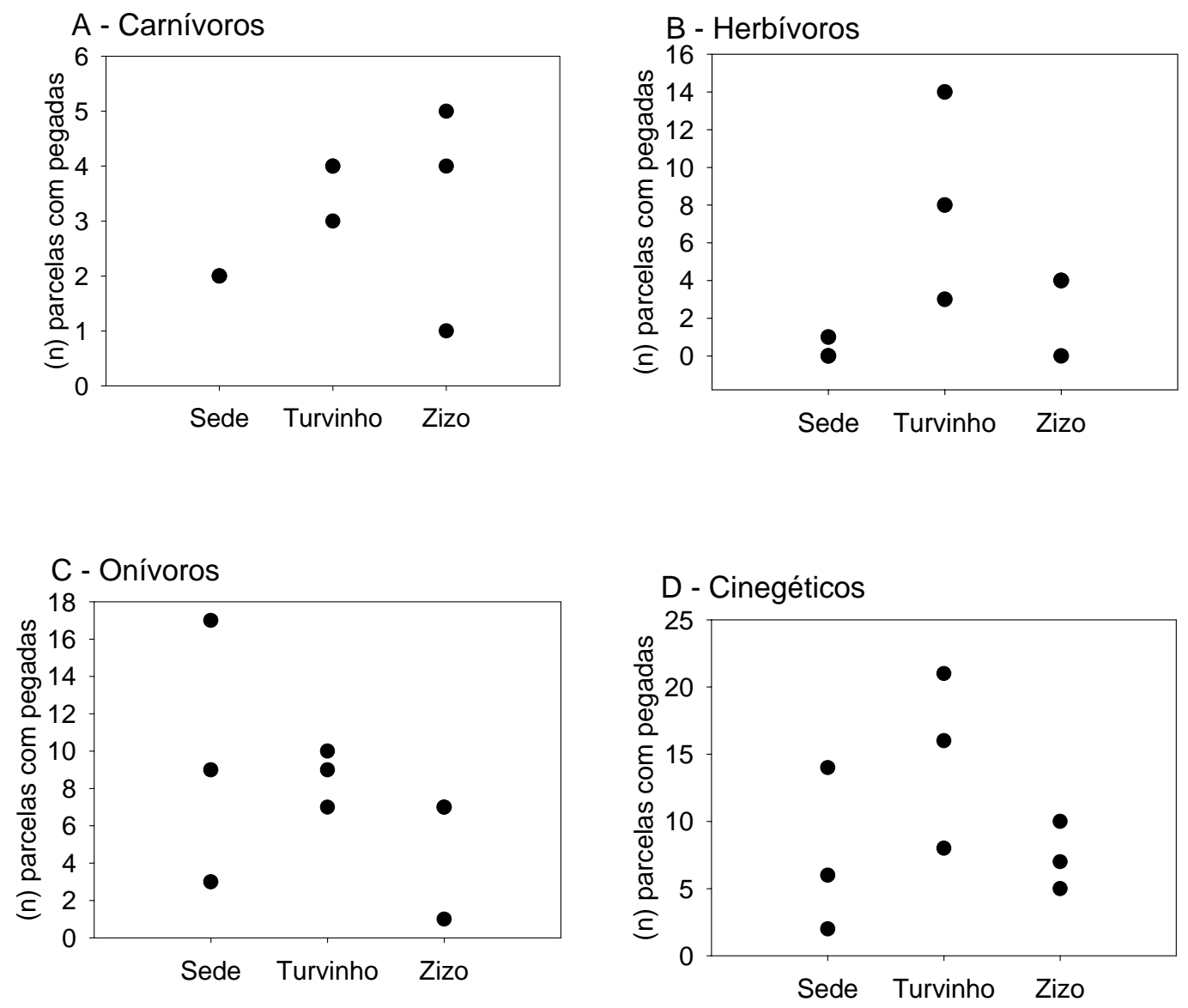

Figura 11 - Freqüência de ocorrência das Guildas e Cinegéticos nas trilhas, durante as sessões de vistoria, utilizando o tipo de registro presença na trilha 
Segundo o tipo de registro presença na parcela, os carnívoros tiveram uma freqüência de ocorrência maior nas trilhas do Zizo e da Sede em relação ao Turvinho. Por outro lado, os herbívoros utilizaram com maior freqüência as trilhas do Turvinho e Zizo em relação à Sede, e os onívoros utilizaram mais as trilhas da Sede, seguido do Turvinho e Zizo. Já as espécies cinegéticas foram mais registradas nas trilhas do Turvinho em relação à Sede e o Zizo, que apresentaram freqüências parecidas. Os onívoros tiveram menor variação entre as trilhas no Zizo, utilizando-as com freqüências parecidas. (Figura 12).
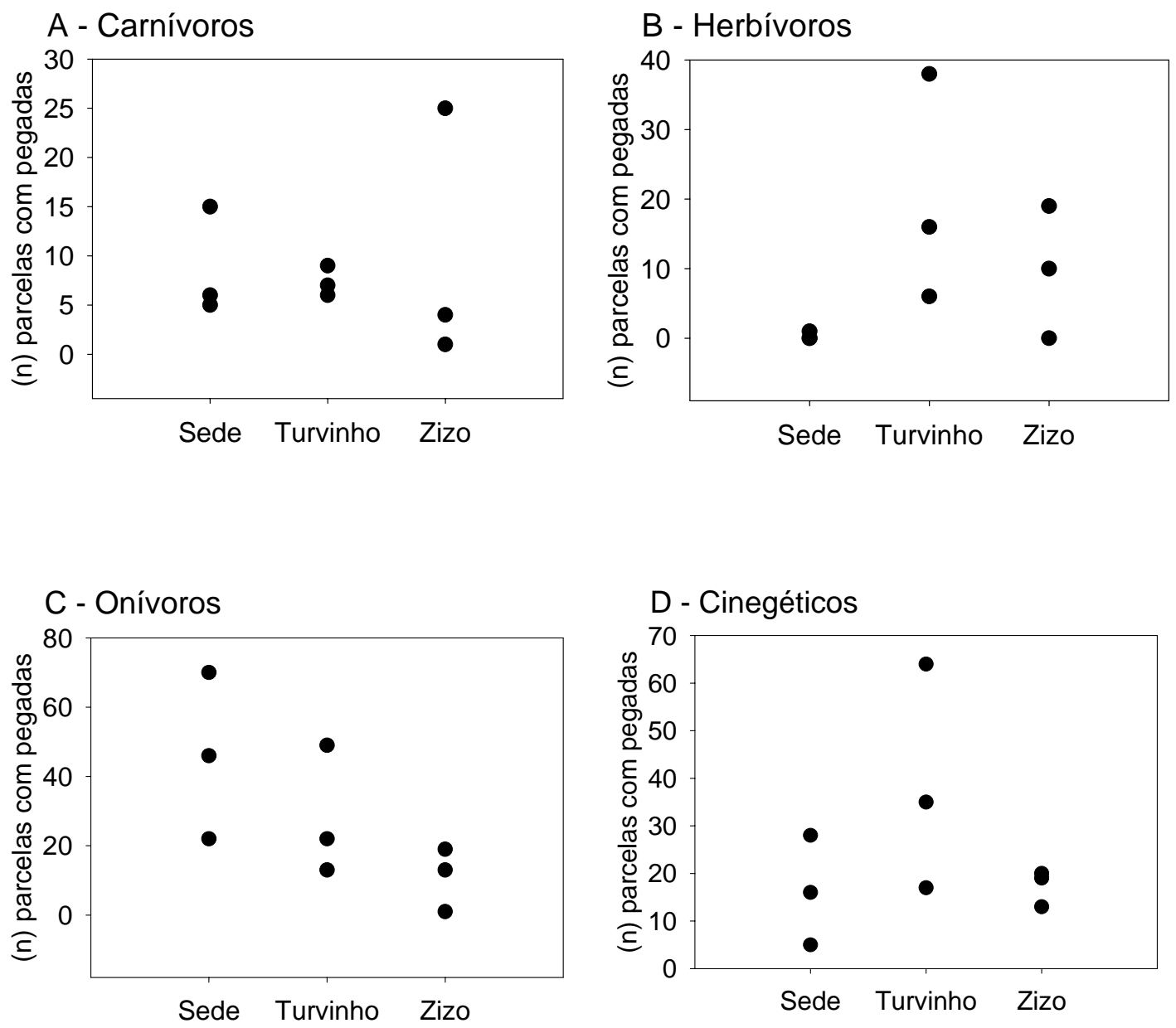

Figura 12 - Freqüência de ocorrência Guildas e Cinegéticos nas trilhas, por sessão de vistoria, utilizando o tipo de registro presença na parcela 
Ocorreram diferenças significativas no número de registros das espécies de médios e grandes mamíferos entre as épocas de coleta no ano $(H=14,4$, g.1. $=2 ; p<0,05)$ (Figura 13). O maior número de registro foi na estação seca (sessão 3), seguido da estação intermediária (sessão 2) e chuvosa (sessão 1). Este resultado demonstra que a época de melhor utilização do método de parcelas de areia é na estação seca, onde as parcelas não são destruídas pela chuva e nem as pegadas são apagadas, aumentando a probabilidade de obter registros de pegadas nítidos e confiáveis.

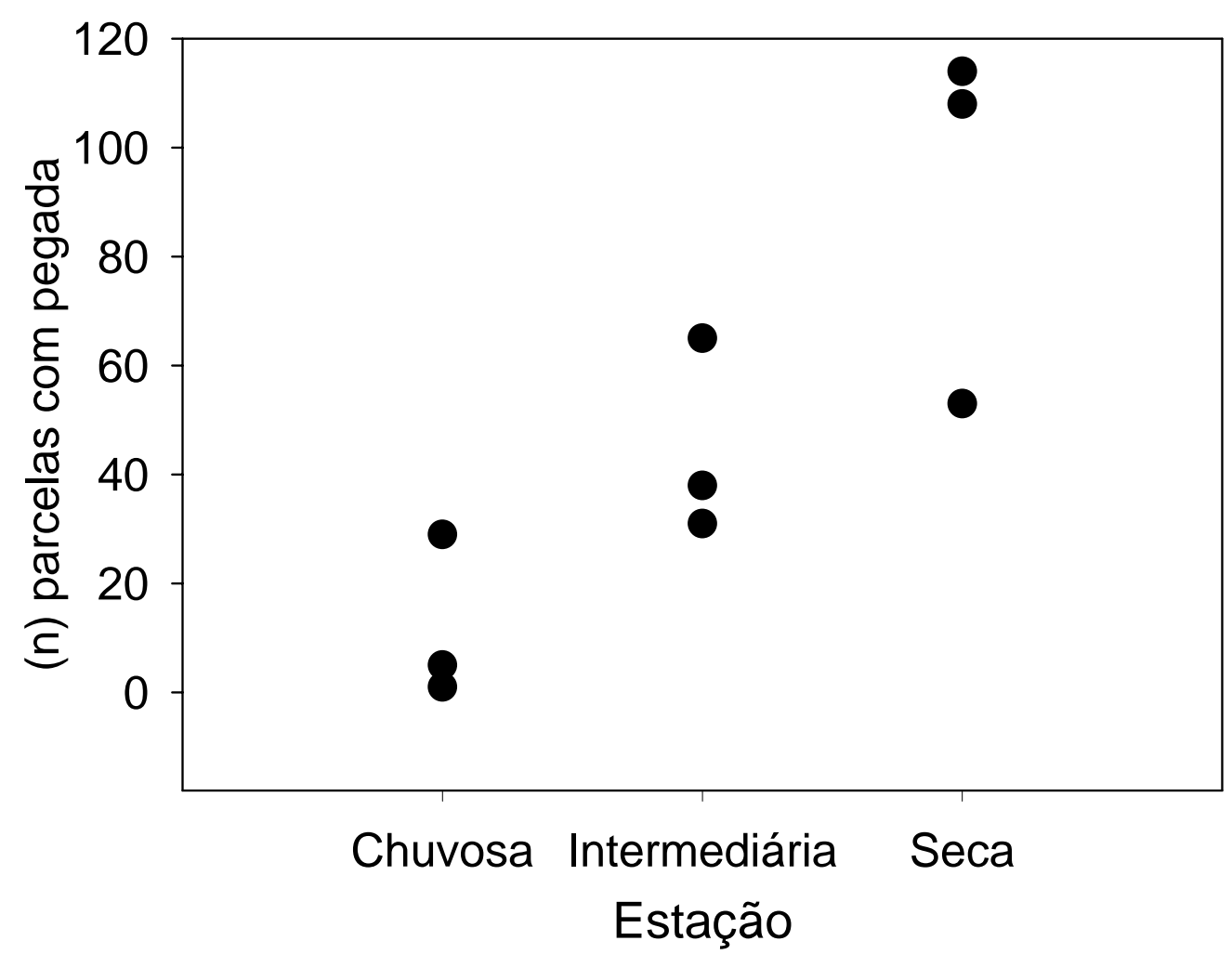

Figura 13 - Número de registros de médios e grandes mamíferos em cada trilha, nas três sessões de coletas realizadas nas diferentes estações do ano 


\subsection{Avistamentos de mamíferos terrestres de médio e grande porte}

Durante o período de Janeiro a Agosto de 2003 foi percorrido o total de 225,1 km de trilhas nas áreas estudadas. Na Sede (PECB) foram percorridos 80,7 km nas trilhas escolhidas para o estudo, na Base Turvinho (PECB) 74,2 km e no Parque do Zizo 70,2 $\mathrm{km}$. Durante este período foram obtidos 28 registros de observações diretas de 10 espécies de mamíferos de médio e grande porte. Destas, quatro espécies são terrestres (Tapirus terrestris, Agouti paca, Euphractus sexcinctus e Puma concolor), duas são escansoriais (Nasua nasua e Eira barbara), três são arborícolas (Brachyteles arachnoides, Allouata guariba e Cebus a. nigritus) e uma aquática (Lontra longicaudis).

O Parque do Zizo apresentou um táxon a mais que as outras áreas, Base Turvinho e Sede apresentaram o mesmo número de espécies. A área da Sede apresentou o maior número de avistamentos, seguido da Base Turvinho e Parque do Zizo (Tabela 16). A espécie mais avistada no período de estudo foram os primatas, muriqui (Brachyteles arachnoides), 30,7\% e o bugio (Allouata guariba), 25\% das avistamentos totais.

Em relação ao número de indivíduos, na área da Sede a espécie mais numerosa foi o macaco-prego (60\%) e o muriqui (20\%), sendo o muriqui a espécie mais avistada nesta área $(\mathrm{n}=4)$. Na Base Turvinho o muriqui $(44,1 \%)$ e o bugio $(32,3 \%)$ foram as espécie mais numerosas, nesta área a espécie mais avistada foi o bugio $(n=3)$. No Parque do Zizo também foi o muriqui $(41,6 \%)$ a espécie mais numerosa, em seguida o macacoprego $(29,1 \%)$, e a espécie mais avistada foi o muriqui $(n=2)$ (Tabela 11).

O restante das espécies foi avistado apenas uma ou duas vezes durante os transectos nas áreas estudadas. Estas espécies possuem hábitos solitários e discretos, e em geral são noturnas e/ou crepusculares, por isso os encontros ocasionais com estas espécies são raros. O Coati (Nasua nasua) apesar de ser uma espécie, que como os primatas, vivem em bandos, são diurnas e de fácil visualização, neste estudo não apresentou a mesma porcentagem de avistamentos $(7,1 \%)$ como as outras três espécies de primatas (muriqui 28\%, bugio 21,4\% e o macaco-prego $17,8 \%$ dos avista mentos totais nas áreas estudadas). 
Tabela 15 - Avistamentos das espécies e de indivíduos de mamíferos de médio e grande porte, registrados nos transectos da área da Sede (80,2 km percorridos), Base Turvinho (74,2 km) e Parque do Zizo (70,2 km)

\begin{tabular}{|c|c|c|c|c|c|c|c|}
\hline \multirow{2}{*}{ Espécie } & \multirow{2}{*}{ Nome popular } & \multicolumn{2}{|c|}{ Sede } & \multicolumn{2}{|c|}{ Base Turvinho } & \multicolumn{2}{|c|}{ Parque do Zizo } \\
\hline & & Avistamentos ${ }^{1}$ & Indivíduos $^{1}$ & Avistamentos & Indivíduos & Avistamentos & Indivíduos \\
\hline Allouata guariba & Bugio & $2(0,24)$ & $9(1,1)$ & $3(0,4)$ & $11(1,48)$ & $1(0,14)$ & $3(0,42)$ \\
\hline Brachyteles arachnoides & Muriqui & $4(0,5)$ & $15(1,85)$ & $2(0,26)$ & $15(20,2)$ & $2(0,28)$ & $10(1,42)$ \\
\hline Cebus a. nigritus & Macaco-prego & $3(0,37)$ & $45(5,57)$ & $1(0,13)$ & $5(0,67)$ & $1(0,14)$ & $7(1)$ \\
\hline Tapirus terrestris & Anta & - & - & $2(0,26)$ & $2(0,26)$ & - & - \\
\hline Euphractus sexcinctus & Tatu-peludo & $1(0,12)$ & $1(0,12)$ & - & - & - & - \\
\hline Agouti paca & Paca & - & - & - & - & $1(0,14)$ & $1(0,14)$ \\
\hline Lontra longicaudis & Lontra & - & - & - & - & $1(0,14)$ & $2(0,28)$ \\
\hline Nasua Nasua & Coati & $2(0,24)$ & $5(0,61)$ & - & - & - & - \\
\hline Eira barbara & Irara & - & - & - & - & $1(0,14)$ & $1(0,14)$ \\
\hline Puma concolor & Onça-parda & - & - & $1(0,13)$ & $1(0,13)$ & - & - \\
\hline Total de avistamentos & & $12(1,36)$ & $75(9,3)$ & $9(0,94)$ & $34(4,58)$ & $7(1)$ & $24(3,41)$ \\
\hline Total de espécies & & 5 & & 5 & & 6 & \\
\hline
\end{tabular}

\footnotetext{
${ }^{1}$ (avistamentos/10 km)
} 


\section{DISCUSSÃO}

\subsection{Aspectos sócio-econômicos da população residente no entorno das áreas estudadas}

Os entrevistados no entorno da Sede (PECB) apresentam uma condição sócioeconômica melhor do que os entrevistados da Base Turvinho (PECB) e Parque do Zizo, devido a melhores condições locais de infra-estrutura, como acesso facilitado pela estrada de asfalto e deslocamento até a cidade pelo transporte público diário, diferente das outras áreas que apresentam estradas em péssimas condições, impedindo que o transporte público alcance às propriedades mais afastadas, dificultando o acesso dos moradores à área urbana.

As áreas da Base Turvinho e Parque do Zizo apresentam características semelhantes em relação às atividades realizadas nas propriedades localizadas em seu entorno, na maioria, pequenos produtores de feijão, arroz, mandioca, banana e hortaliças para subsistência.

Os bairros mais próximos estão distantes cerca de $10 \mathrm{~km}$, o que dificulta a obtenção diária de carne e outros suprimentos alimentares. Por isso há necessidade de fazer pequenas plantações e a criação de animais domésticos, tais como galinha e porco. Frequentemente as plantações, ou roças, como chamadas na região, são atacadas por animais silvestres. A anta (Tapirus terrestris) e o veado (Mazama spp.) costumam atacar as roças de feijão e mandioca, e a lebre-européia considerada como espécie praga nos últimos anos no Estado de São Paulo (Auricchio \& Olmos, 1999; Cavalcanti, 2003) costumam atacar todas as culturas, inclusive as hortas, enquanto predadores como gaviões e pequenos felinos atacam galinhas. 
Houve apenas um relato de ataque a bezerros pela onça-parda (Puma concolor) na região do Parque do Zizo. Em muitos dos relatos os moradores descrevem estas situações para justificar a caça de subsistência que ocorre na região, afirmando que além da distância das moradias dos bairros, a perda de alimento para animais silvestres, os leva a recorrer aos recursos naturais da floresta.

Segundo Cândido (1977) citado por Hanazaki (2001), no interior paulista a caça era uma atividade ocasional, praticada apenas esporadicamente e estava relacionada à defesa das roças. Esta defesa ocorre nas áreas estudadas, especialmente com os veados e antas, que causam muitos prejuízos as roças.

\subsection{O uso de recursos naturais: Caça e extrativismo vegetal}

Segundo Adams (2000a) citado por Hanazaki (2001), o uso fauna como recurso alimentar na região do litoral sul do Estado de São Paulo em geral é esporádico e atualmente de menos freqüente que no passado, devido à abertura de estradas de comunicação com o litoral, a introdução do barco a motor e, certamente, da legislação que regula esta atividade. Porém, a caça ocorre em diferentes intensidades em outras regiões de Floresta Atlântica (Chiarello \& Melo, 2001; Cullen, 2000, 2001), onde ainda não há estudos conclusivos sobre seu efeito sobre as populações na região.

Segundo Cullen (2001) as espécies mais caçadas pelos colonos nos fragmentos florestais do Pontal do Paranapanema são herbívoros terrestres, com os primatas sendo apenas raramente caçados. Na região da Serra de Paranapiacaba as espécies preferidas pelos moradores também foram os herbívoros terrestres, especialmente a paca, o veado, os porcos-do-mato e diferente dos fragmentos do Pontal, os primatas também foram citados nas entrevistas com a população local e no censo de primatas realizado por Gonzáles-Solis et al. (2002); mesmo padrão dos estudos em floresta contínuas da Amazônia (Emmons, 1984; Peres, 1990; Bodmer, 1995; Bodmer et al., 1997).

Neste estudo a freqüência de ocorrência dos mamíferos onívoros de médio e grande porte foram maiores nas áreas sem pressão de caça e com maior físcalização, porém os herbívoros e espécies cinegéticas foram mais registrados nas áreas com 
pressão de caça, indicando que outros fatores podem influenciar na abundância destas espécies, além da pressão de caça em áreas contínuas de Floresta Atlântica.

Em fragmentos no pontal do Paranapanema Cullen et al. (2001) observou que a abundância relativa de antas, queixadas, tatus e quatis diminuíram nos locais de intensa pressão de caça enquanto a abundância de catetos, pacas e primatas não tiveram relação com a pressão de caça. Segundo Chiarello (1999) a abundância de bugios (Alouatta fusca) e as taxas de avistamentos de veados, porcos-do-mato, pacas e cotias foram maiores em áreas de Floresta Atlântica preservadas sem pressão de caça no Espírito Santo, mostrando como a pressão de caça é mais evidente e seus efeitos mais perceptíveis e danosos para a população das espécies de mamíferos de médio e grande porte em fragmentos florestais.

Além da caça ocorre outro tipo de exploração de recursos naturais na Serra de Paranapiacaba, o corte de palmito (Euterpe edulis), que é ainda mais evidente, porém os efeitos desta exploração ilegal para a população desta palmeira e como alimentação para fauna também não são fáceis de identificar.

Nas áreas com mais fiscalização, como é o caso da Sede e Turvinho a exploração do palmito ocorre em menor freqüência, do que nas áreas de entorno do PECB, como o Zizo. Segundo informações do programa de fiscalização do PECB, as áreas localizadas no planalto apresentam um perfil diferenciado (Anexo A), na região do Taquaral, Capote e Turvinho, apesar da ocorrência periódica de invasão do parque para o roubo do palmito, da ação igualmente constatada de participação dos bairros do entorno, tais como Justinada, Fatura e Ouro fino (região do Parque do Zizo), no beneficiamento e comercialização, a intensidade da atividade extrativista é baixa.

Existem áreas consideradas críticas do ponto de vista de pressão sobre este recurso na região: Saibadela, Guapiruvu, Grota Seca, Rio Preto, Travessão e Ribeirão Fundo. Destacam-se as áreas das zonas de Rio Preto e Guapiruvu, núcleos de ação organizada dos palmiteiros. Praticamente todos os bairros do entorno participam direta ou indiretamente, da atividade, motivados pela situação sócio econômica precária de toda região (Ferraz e Varjabediam, 1999). 


\subsection{Uso de parcelas de areia para o levantamento de espécies de mamíferos de médio e grande porte}

Vale lembrar que este é o primeiro inventário de mamíferos realizado na Reserva Particular Parque do Zizo e Base Turvinho (Parque Estadual Carlos Botelho). A maioria dos dados disponíveis para as espécies de mamíferos de médio e grande porte são de estudos realizados nas áreas próximas à Sede (PECB). Paccagnella (1991) realizou um censo da população de muriquis (Brachyteles arachnoides) percorrendo em dois dias uma trilha e uma estrada na região do Turvinho, não tendo observado a espécie. A ocorrência de apenas um grupo de muriquis foi registrada através de informações de funcionários do parque. Talvez, esses resultados sejam reflexo de que algumas regiões florestais onde a densidade de mamíferos relativamente baixas torna o método de censo pouco eficaz, especialmente em estudos de curto prazo (Pardini et al., 2003, Cullen \& Rudran, 2003).

Como os resultados alcançados pelos censos visuais se aproximam dos obtidos com parcelas de areia, este método se mostra como uma alternativa para estudos de populações de mamíferos silvestres terrestres em regiões tropicais (Dirzo \& Miranda, 1990), principalmente de animais de difícil observação, como os mamíferos noturnos: gambá, paca, tapiti e cachorro-do-mato (Pardini et al., 2003). As espécies mais freqüentes nas parcelas de areia também foram o cachorro-do-mato, gambá, gato-domato, anta e paca, confirmando a eficácia do método para animais de hábitos noturnos, difíceis de registrar em censos visuais.

O método das parcelas de areia foi utilizado neste estudo para se comparar a freqüência de ocorrência das espécies de médios e grandes mamíferos entre áreas com diferentes intensidades de pressão antrópica, considerando que em locais de caça intensa, estes animais se afastam ou apresentam comportamentos sociais alterados pela presença humana (Verdade, 1996). As áreas estudadas possuem grandes extensões de

floresta com o relevo bastante acidentado, o que dificulta à caminhada nas trilhas e consequentemente o encontro e contagem dos animais, portanto, a utilização do método 
das parcelas de areia se mostrou muito adequado às condições de relevo e pressão antrópica das áreas e também temporais e econômicas deste estudo.

Comparando o esforço amostral e a riqueza de espécies com outros estudos que utilizaram parcelas de areia, nota-se que mesmo com maior esforço amostral o número de espécies de médios e grandes mamíferos não aumenta substancialmente. Neste estudo com 2.700 parcelas de areia monitoradas foi possível registrar 15 espécies de médios e grandes mamíferos. Apesar de não descrever seu esforço amostral Silva (2001) também, registrou a mesma riqueza, enquanto Scoss (2002) em 1200 parcelas registrou 16 espécies e Pardini (2001) em um total de 6.912 parcelas também registrou 16 espécies.

\subsubsection{Aspectos metodológicos: o uso de diferentes tipos de registro em parcelas de areia}

Alguns tipos de registro apresentam-se tendenciosos em relação aos aspectos biológicos das espécies, como o tipo pegadas na parcela. O número de pegadas nas parcelas está relacionado ao tamanho do animal, ou seja, animais maiores deixam menos pegadas que os animais menores, com passadas mais curtas. Por exemplo, a anta possui uma passada de $50 \mathrm{~cm}$ e o gambá de $12,5 \mathrm{~cm}$, então, enquanto uma anta deixa uma ou duas pegadas em uma parcela de 50 x $50 \mathrm{~cm}$, o gambá deixa 5 ou 6 pegadas, considerando ambos representados por um único indivíduo.

Nos tipos de registro onde se contabiliza a passagem e presença na parcela, cada registro consiste da presença de rastros de uma espécie em uma parcela em um dia, independentemente do número de pegadas na parcela (Pardini, 2001; Pardini, et al., 2004; Silva, 2001; Scoss, 2002) a variável tamanho da passada não influencia. Porém, como na contagem das passagens se considera como registros independentes pegadas em diferentes direções (ida e volta), este tipo de contagem apresenta uma tendência a superestimar a freqüência das espécies que apresentam o comportamento de percorrer a mesma trilha diversas vezes no mesmo dia. Esse parece ser o caso do cachorro-do-mato neste estudo, que em um único dia deixou 48 registros de passagens nas parcelas de uma 
mesma, na área da Sede. Este tipo de registro se mostra mais eficiente como medida de freqüência de uso na trilha do que de abundância das espécies.

O tipo de registro presença na parcela também tem uma tendência de registrar animais que utilizam as trilhas para o deslocamento; nestes casos, a disposição das parcelas estaria tendenciando a amostragem e algumas espécies. Uma alternativa seria modificar essa disposição das parcelas ao longo das trilhas para quadrantes, onde os animais que costumam seguir as trilhas não sejam mais registrados em todas as parcelas, aumentado a independência entre elas (com. pess. Renata Pardini 2004), ou para o caso de espécies de maior porte, aumentando o espaçamento de 10 para $30 \mathrm{~m}$ como sugerido por Scoss (2002), apesar das espécies de maior porte ainda serão mais registradas.

Já no tipo de registro presença na trilha, que apresenta a maior independência nos dados, poucas espécies obtiveram um número de registros suficientes para as análises, indicando que neste tipo de registro devido a perda de sensibilidade o esforço amostral deve ser muito maior do que para os outros.

Os aspectos ecológicos e biológicos das espécies como, tamanho corporal, preferência de habitat (Silva, 2001), tamanho da área de vida e organização social (Scoss, 2002; Pardini et al., 2003) podem influenciar na freqüência das espécies medida pelas parcelas de areia, principalmente, em estudos que consideram mais de uma espécie ou grupo ecológico, pois podem tornar o protocolo inadequado para algumas espécies.

O Coati (Nasua nasua) foi responsável por 7,6\% dos registros de passagem nas parcelas da área da Sede, esta baixa freqüência de ocorrência nas parcelas pode estar relacionada com a preferência pelo estrato arbóreo. Beisiegel (2001) observou que a espécie tem preferência pelo estrato arbóreo, quando em $90 \%$ dos encontros com a espécie observou o forrageamento em bromélias epífitas, preferência relacionada à abundância deste recurso na Floresta Atlântica. Silva (2001) em seu estudo não registrou esta espécie nas parcelas de areia em remanescentes de Floresta Atlântica, porém esta espécie foi registrada por outros métodos.

O cachorro-do-mato (Cerdocyon thous) foi responsável por $65,5 \%$ do total de registros de passagens na Sede. Como neste tipo de contagem se considera como registros independentes pegadas em diferentes direções (ida e volta), é possível que um 
ou poucos indivíduos sejam responsáveis por essa elevada freqüência de ocorrência. Esta espécie tem o hábito de utilizar trilhas para o deslocamento entre grandes áreas, devido a sua estratégia de forrageamento (Beisiegel, 2000), e como as parcelas estão dispostas ao longo da trilha, a tendência deste animal é pisar em todas elas. Este resultado indica, portanto que este animal utiliza frequentemente as trilhas para o deslocamento, principalmente as trilhas da Sede, onde a presença humana é menor. Segundo Facure (1996), alterações na área de vida e densidades de indivíduos desta espécie podem ocorrer devido ao aumento da oferta de recursos pela presença humana.

Neste estudo o método de parcelas de areia não se mostrou muito eficaz para algumas espécies, como cervídeos (Mazama spp.). Em uma das trilhas do Turvinho, suas pegadas foram encontradas duas vezes ao lado das parcelas, indicando que ele evitou pisar no substrato diferenciado da trilha. Como estas espécies apresentam comportamento anti-predatório, utilizando riachos para despistar seus odores dos predadores (Vogliotti et al., 2002), é possível que este indivíduo tenha sentido odores diferenciados na areia da parcela, que o fez evitar este substrato.

Como a espécie Canis familiaris (cão doméstico) foi registrada apenas no Turvinho, e neste local as residências estão mais próximas à borda da mata e consequentemente das trilhas utilizadas no estudo, pode ser que este animal seja muito mais cauteloso na utilização das trilhas do que em outras áreas. Entretanto, no Zizo foram registradas pegadas de uma fêmea de veado-mateiro (Mazama americana) com filhote em todas as parcelas de uma trilha. Este fato ocorreu na terceira sessão de vistoria durante o mês de agosto, o que coincide com os dados de época de nascimentos de filhotes obtidos por Vogliotti et al. (2002) através de armadilhas fotográficas no Parque Estadual Intervales.

As duas espécies de porcos-do-mato (Tayassu pecari e Pecari tajacu) não foram visualizadas e foram registrados uma vez nas trilhas através de rastros, porém fora das parcelas de areia. Segundo Pardini et al. (2003) a abundância relativa destas espécies não pode ser expressa adequadamente através de pegadas nas parcelas de areia, por causa de sua organização social. O fato de estes animais realizarem "migrações" percorrendo grandes distâncias em áreas de floresta dificulta o registro no método de parcelas de 
areia e transectos lineares (Fragoso, 1994). Em áreas de floresta contínua a dificuldade de encontrar estes animais é maior do que fragmentos isolados, sendo necessário um grande esforço amostral para estimativas mais precisas. Esta baixa freqüência de registros destas espécies nas áreas estudadas, pode estar relacionada as densidades muito baixas causadas provavelmente pela pressão da caça exercida na região durante anos (Silva, 2001). Outros estudos também apontam à diminuição de queixadas (Tayassu pecari) devido a pressão de caça em fragmentos florestais no sudoeste do Estado de São Paulo porém o cateto (Pecari tajacu) não apresentou densidades baixas nas áreas com maior pressão de caça (Cullen et al., 2000, 2001).

\subsection{Avistamentos de mamíferos terrestres de médio e grande porte}

Os dados dos levantamentos populacionais através de transectos lineares realizados neste estudo não tiveram um número de observações suficientes para análise de densidade por área das espécies, para estimativas mais precisas recomenda-se um número mínimo de 40 observações independentes para cada área estudada (Cullen \& Rudran, 2003). Porém foi possível calcular a taxa de avistamento para as espécies mamíferos de médio e grande porte registradas através deste método, os resultados apontam a maior abundância na área da Sede, o que era o esperado devido à ausência de pressão de caça e uma menor presença humana, seguido do Turvinho e Parque do Zizo, que apresentaram menor número de indivíduos dentre as espécies de primatas (muriqui, Bugio e Macaco-prego), o que pode estar refletindo na diminuição do tamanho dos grupos devido à pressão de caça, como observado por Peres (1990) na Amazônia.

A preferência dos moradores da região também pela carne de primatas, em especial pelo muriqui, já é relatada desde 1928 para região da Serra de Paranapiacaba e Vale do Ribeira (Lane, 1977), e que ainda ocorre nos dias de hoje segundo relatos dos moradores e caçadores da região e segundo Chiarello (2001) o muriqui e os bugios são primatas grandes e sedentários, o que facilita a ação dos caçadores. Segundo este autor, as densidades dos bugios e macacos-prego foram maiores nas áreas com baixa pressão de caça no Espírito Santo. 


\subsection{Comparação da freqüência de ocorrência das espécies de mamíferos de médio e grande porte entre as áreas com diferentes pressões antrópicas}

Bruner et al. (2001) analisando diferentes tipos de pressões antrópicas em 93 áreas protegidas de 22 países, observaram que a caça e o desmatamento são os tipos de pressões que mais afetam estas áreas, porém em menor intensidade que áreas do entorno, que não possuem fiscalização e proteção legal dos recursos naturais. As áreas no entorno Parque Estadual Carlos Botelho estão sofrendo uma maior pressão antrópica, como é o caso da Base Turvinho que apresenta sinais de pressão antrópica (caça e extração de palmito) e o Parque do Zizo, que faz parte do seu entorno onde segundo os relatórios de fiscalização sofre uma maior pressão de extração de palmito, e menor pressão de caça.

Os dados de observações diretas de atividades de caça no ano de 2001 (Tabela 2) reforçam a intensa pressão de caça sofrida no Zizo, neste ano os dados da fiscalização também registraram o maior número de ocorrências de caça na área. Porém nos últimos dois anos devido à presença constante de funcionários e turistas no Zizo, os palmiteiros e caçadores não estão sendo frequentemente observados como antigamente, Esses dados mostram que a fiscalização e o aumento da presença humana em ambas as áreas de estudo, estão refletindo na diminuição destas atividades. Durante este período a pressão de caça foi considerada ausente na Sede e moderada no Turvinho e Zizo quando comparadas ao ano de 2001.

Nas áreas mais fiscalizadas há uma maior freqüência de ocorrência de mamíferos de médio e grande porte, devido à inibição das atividades ilegais (caça e extração de palmito) que nas áreas sem fiscalização. Os dados deste estudo suportam esta hipótese, pois a área que apresentou a menor freqüência de ocorrência de espécies foi o Zizo, que apresentou pressão de caça em diferentes intensidades (2001 e 2003), intensa extração de palmito e não possui fiscalização de rotina. O Turvinho que também apresenta pressões antrópicas como o Zizo, porém possui fiscalização de rotina, apresentou um número de registros das espécies ( $\mathrm{n}=166$ ), bem próximo da Sede ( $\mathrm{n}=168$ ) que não possui pressão antrópica e está entre as regiões mais fiscalizadas do PECB. 
De acordo com os resultados não foi possível fazer inferências sobre a diminuição na densidade das espécies de mamíferos de médio e grande porte, por causa especificamente da caça. Devido à heterogeneidade entre as trilhas, os efeitos da pressão de caça não são aparentes, existem outros fatores que influenciam no uso das trilhas de cada área, dificultando a percepção dos efeitos causados apenas pela caça. Porém podese inferir que em locais com maior presença humana predatória, neste caso, somando as atividades de caça e extração de palmito, além da ausência de fiscalização, as espécies tendem a apresentar uma menor freqüência de ocorrência.

Segundo Verdade (1996) a pressão de caça pode afetar além da demografia, aspectos comportamentais como territorialidade, que pode ser um fator para explicar as diferenças na freqüência de ocorrência das espécies entre as trilhas de uma mesma área com maior presença humana. Espécies como felinos e grandes herbívoros podem mudar seu comportamento de utilização da área em razão do fluxo de pessoas no local (Van Dyke et al., 1986b; Scoss, 2002), como é o caso dos onívoros que apresentaram maior freqüência de ocorrência na área da Sede, onde a presença humana é menor.

A diferença nas freqüências de ocorrência dos herbívoros entre as áreas pode estar relacionada também ao habitat no entorno dos locais onde foram colocadas as parcelas de areia. Na área do Turvinho, a elevada freqüência de herbívoros pode ser explicada pela proximidade das trilhas com a Represa São José. Como estes animais em geral preferem ou estão associados a cursos d água, sua presença nas trilhas desta área será maior (Vogliotti et al., 2002; Emmons, 1997; Eisenberg \& Redford, 1999 e Naranjo, 1995). Na área da Sede, a baixa freqüência de herbívoros em comparação as outras áreas estudadas, pode estar relacionada à época de coleta de dados. As pegadas de herbívoros como a paca, a anta e o veado são freqüentes nas trilhas desta área (com.pess. Beisiegel, B. 2004), porém no período de estudo foram nulos, e como as espécies cinegéticas, na maioria são herbívoros, as freqüências de ocorrência deste grupo também foram maiores no Turvinho.

As áreas de estudo estão localizadas no continnum ecológico de Paranapiacaba, que tem aproximadamente 140.000 hectares de floresta em diferentes estágios sucessionais, protegidas em unidades de conservação estaduais e áreas privadas 
contíguas (Mateos et al., 2002), o fato de estarem inseridas neste contínuo pode ser outro fator para não apresentarem ainda sinais de diminuição das populações de mamíferos de médio e grande porte, pois a área de Sede pode estar contribuindo como área fonte de novos indivíduos que estão sendo caçados nas áreas do entorno com pressão de caça, como o Turvinho e Zizo.

As áreas com pressão de caça representam "ralos" por onde são perdidos indivíduos das espécies, porém devido à dispersão, são substituídos por uma "fonte" de novos indivíduos advindos de áreas sem pressão do entorno. Esta dispersão tem um papel importante na recuperação das populações animais com abundância reduzida pela caça e sustentabilidade da caça, dependendo do tamanho da área de entorno sem pressão específica para cada espécie. Portanto, deve-se considerar os fatores que influenciam fortemente na dispersão (estrutura espacial e tamanho das áreas com e sem caça, tamanho populacional em áreas fonte e comportamento social) (Navaro et al., 2000). Se esta fonte "secar", ou seja, todas as áreas apresentarem pressões de caça intensa, ou quem sabe até moderada, a conseqüência ao longo do tempo é certamente a empty forest, termo em inglês para floresta vazia (Redford, 1992). 


\section{CONCLUSÕES}

$\checkmark$ O uso do método de parcelas de areia possibilita realizar inventários rápidos em grandes áreas, de baixo custo financeiro, além de permitir, conhecer e comparar a abundância de espécies de difícil observação, através de um método padronizado em diferentes áreas. A melhor época de utilização do método é a na estação seca.

$\checkmark$ As principais diferenças entre os tipos de registro nas parcelas de areia foram causadas pelo tamanho da parcela em relação ao tamanho do animal, falta de independência entre as parcelas e habitat no entorno das trilhas.

$\checkmark$ A Sede apresentou o maior número de registros nas parcelas de areia e avistamentos, seguido do Turvinho e Zizo. Os onívoros são mais freqüentes na Sede, os herbívoros e cinegéticos no Turvinho e os carnívoros no Zizo.

$\checkmark$ A heterogeneidade entre as trilhas, a localização das áreas em um remanescente de florestal contínuo e a dificuldade de quantificar a pressão de caça, dificulta a percepção dos efeitos causados apenas pela caça.

$\checkmark$ Os locais com maior freqüência de atividades de caça, extração de palmito e ausência de fiscalização apresentaram uma menor freqüência de ocorrência mamíferos de médio e grande porte.

$\checkmark$ No período deste estudo, as atividades de caça foram menos registradas no Parque do Zizo, provavelmente, devido a freqüente presença de funcionários e turistas nos últimos anos que estão inibindo esta atividade.

$\checkmark$ Recomenda-se o uso dos relatórios da fiscalização na avaliação dos impactos humanos em áreas protegidas, pois é uma fonte rica de informação sobre o uso dos recursos naturais e seus locais mais freqüentes de exploração. 
ANEXOS 
Anexo A

Modelo de relatório da fiscalização do Parque Estadual Carlos Botelho

SÃO MIGUEL ARCANJO - CAPÃO BONITO

1 - DATA:-

$1+1$

2 --VEICULOS:-

3-REGIÃO DO TURVINHO:Base Turvinho( );Curupira( ); Marco 8( ); Formitex(ex-Plástico Brasil) ( ); Fantura ( ); Ouro Fino ( ); Delfino ( ); Caçador( ); S.Bartolomeu( ). REGIÃO CAPOTE: Marquesa( ); Oueiroz( ); Fazenda 110 ( ); Capote( ; Barro Brancó ).

4-VIGIAS:-

\section{5-PARQUES ENVOLVIDOS:}

6- POLICIA AMBIENTAL DE:

N'DE POLICIAIS:

OUTROS:

7 - APREENSÃ(ÔES) REALIZADA(S)/OUANTIDADE(S):

ARMAS:

PALMITO:

VIDROS:

OUTROS:

8-PROVIDÊNCIAS: 
Anexo B

\section{ROTEIRO DAS ENTREVISTAS}

No

Local:

Data:

Hora:

Nome Idade:

Permissão para gravar: ( )sim ( )não - Estado Civil: ( )solteiro ( )casado Quantos filhos:

1) Há quanto tempo mora na região e qual o local de origem?

2) Qual o número de pessoas na família?

3) Qual a ocupação de trabalho? Da família?

4) Possui criação de animal doméstico ou silvestre? Quais e Quantos?

5) Tem roça? De que? Quanto?

6) Tem cachorros? Quantos?

Caracterização das propriedades

7) Qual o tamanho da propriedade? E quais a atividades?

8) O proprietário mora no local?

Caracterização das atividades de caça

9) Qual a última vez que caçou?

10) Qual o melhor lugar para caçar na região?

11) Qual a técnica(s) de caça que utiliza?

12) Qual a melhor época e horário para caçar?

13) Qual animal de caça é o seu preferido? Por quê?

14) Quais animais de caça estão mais ou menos comuns hoje em dia?

15) Qual animal se tornou raro na região?

16) A fiscalização do parque e da polícia afasta as pessoas que caçam e cortam palmitos? 


\section{REFERÊNCIAS BIBLIOGRÁFICAS}

AURICCHIO, P.; OLMOS, F. Northward range extension for the european hare, Lepus europaeus, Pallas, 1778 (Lagomorpha - Leporidae) in Brazil. Publs. Avulsas do Instituto Pau Brasil, n.2, p. 1-5, 1999.

AYRES, J.M. Uakaris and amazonian flooded forest. Cambridge,1986. 388p.Thesis (Ph.D.) - University of Cambridge.

AYRES, J.M.; AYRES, C. Aspectos da caça no alto rio Aripuanã. Acta Amazônica, v. 9, n.2, p.287-298, 1979.

BECKER, M. Aspectos da caça em algumas regiões do cerrado do Mato Grosso. Brasil Florestal, v. 11, n. 4, p.51- 63, 1981.

BECKER, M.; DALPONTE, J.C. Rastos de mamíferos silvestres brasileiros. 2.ed. Brasília: Universidade de Brasília: EDUNB, DF,1999. 180p.

BEISIEGEL, B. M. Contribuição ao estudo da história natural do cachorro-do-mato (Cerdocyon thous) e do cachorro-vinagre (Speothos venaticus). São Paulo, 2000.123p. Tese (Doutorado) - Instituto de Psicologia, Universidade de São Paulo. 
BEISIEGEL, B. M. Notes on the coati, Nasua nasua (Carnívora: Procyonidae) in an Atlantic forest area. Brazilian Jounal of Biology, v.61, n.4, p.689-692, 2001.

BERNARDES, A.T., MACHADO, A.B.M., RYLANDS. A.B., Fauna brasileira ameaçada de extinção. Brazilian fauna threatened with extinction. Belo Horizonte, MG: Editora e Gráfica de Ação Comunitária,1989. 62p.

BIDER, J.R. Animal activity in uncontrolled terrestrial communities as determined by a sand transect technique. Ecological Monographs, v. 38, n. 4, p.269-307,1968.

BODMER, R.E.; ACOSTA, N.Y.B.; IBANEZ,L.M.; FANG,T.G. Manejo de Ungulados en La Amazonia Peruana: Análisis de su Caza y Comercialización. Boletim de Lima, v.70, p.49-56, 1990

BODMER, R.E. Managing amazonian wildlife: biological correlates of game choice by detribalized hunters. Ecological Applications, v.5, n.4, p.872-877, 1995.

BODMER, R.E.; PENN JUNIOR, J.W. Manejo da vida silvestre em comunidades na amazônia. In. BODMER, E.R.; VALLADARES-PÁDUA, C. (Org.). Manejo e conservação de vida silvestre no Brasil. Brasília: CNPq; Belém: Sociedade Civil Mamirauá, 1997.1v.

BODMER, R.E.; EISENBERG, J.F.; REDFORD, K.H. Hunting and the likelihood of extinction of Amazonian mammals. Conservation Biology, v.11, n.2, p.460-466, 1997. 
BRUNER, A.G.; GULLISON, R.E.; RICE, R.E; FONSECA, G.A.B.da. Effectiveness of parks in protecting tropical biodiversity. Science, v.291, p.125-128, Jan. 2001.

BUCKLAND, S.T.; ANDERSON, D.R.; BURNHAM, K.P.; LAAKE, J.L. DISTANCE sampling: estimating abundance of biological populations. 1993. Chapaman an hall, London. 1v.

BURNHAM, K.P.; ANDERSON, D.R.; LAAKE, J.L. Estimation of density from line transect sampling of biological populations. Wildlife Monographis, v.72, p.1202,1980 .

CAVALCANTI, S.M.C. Manejo e controle de danos causados por espécies da fauna. In: CULLEN, L. JUNIOR.; RUDRAN, R.; PADUA-VALLADARES, C (Org). Métodos de estudos em biologia da conservação e manejo da vida silvestre. Curitiba: Ed. da UFPR; Fundação O Boticário de Proteção à Natureza, 2003. cap.9, p. 203-242.

CHIARELLO, A.G. Effects of fragmentation of the Atlantic forest on mammal communities in south-eastern Brazil. Biological Conservation, v. 89, p.71-82, 1999.

CHIAREllo, A. G.; MELO, F. R de. Primate poulation densities and sizes in Atlantic Forest remnants of northern Espírito Santo, Brazil. International Journal of Primatology, v.22, n.3, p.379-396, 2001.

COSTA, J.B.N.; CLAYTON, L.F.; CLÁUDIO, C.M.; JOÃO, L.R.A. A Reserva da Biosfera do Estado de São Paulo. São Paulo: Reserva da biosfera da Mata Atlântica. 
CULLEN JUNIOR, L. Hunting and biodiversity in Atlantic forest fragments, São Paulo, Brazil. Florida,1997. 134p.Thesis (Ph.D.) - University of Florida.

CULLEN JUNIOR, L.; BODMER, R.E.; PÁDUA, C.V. Effects of hunting in habitat fragments of the Atlantic Forest, Brazil. Biological Conservation, v.95, p.49-56, 2000.

CULLEN JUNIOR, L.; BODMER, R.E.; PÁDUA, C.V. Ecological consequences of hunting in Atlantic forest patches, São Paulo, Brazil. Oryx, v.35, n.2, p.1-8, 2001.

CULLEN JUNIOR, L.; RUDRAN, R. Transectos lineares na estimativa de densidade de mamíferos e aves de médio e grande porte. In: CULLEN, L. JUNIOR.; RUDRAN, R.; PADUA-VALLADARES, C. (Org). Métodos de estudos em biologia da conservação e manejo da vida silvestre. Curitiba: Ed. da UFPR; Fundação O Boticário de Proteção à Natureza, 2003. cap. 7.p.181-201.

DIRZO, R.; MIRANDA, A.M. Contemporary neotropical defaunation and forest structure, function and diversity - A Sequel to John Terborgh. Conservation Biology, v.42, n.4, p.444-447, 1990.

DIRZO, R.; MIRANDA, A.M. Altered patterns of herbivory and diversity in the forest understory: a case study of the possible consequences of contemporary defaunation. In: WILEY, J. Plant-animal interactions: evolutionary ecology in tropical and temperate regions. New York:, 1991. p. 45-47. 
DOUROJEANNI, M.J. Over-exploited and over-used animals in the Amazon region. In: PRANCE, G.T.; LOVEJOY, T.E. (Ed.) Amazonia (key environments); Pergamon Press Ltd., 1985. cap. 22, p.419-433.

EISENBERG, J.F.; REDFORD, K.H. Mammals of neotropics: The central neotropics. Chicago: The University of Chicago Press, 1999. 190p. v.3.

EMMONS, L. Neotropical rainforest mammals: a field guide (2.ed.). Chicago, 1997. 307p. University of Chicago Press.

ENGEMAM, R.M.; ALLEN, L. Overview of a passive tracking index for monitoring wild canids and associated species. Integrated Pest Management Reviews, n.5, p.197-203, 2000 .

FACURE, K. G. Ecologia alimentar do cachorro-do-mato, Cerdocyon thous (CARNIVORA-CANIDAE), no Parque florestal do Itapetininga, município de Atibaia, sudeste do Brasil. Campinas, 1996. 52p. Dissertação (Mestrado) - Universidade Estadual de Campinas.

FERRAZ, L.P.M.; VARJABEDIAN, B. Evolução histórica da implantação e síntese das informações disponíveis sobre o Parque Estadual Carlos Botelho. São Paulo. SMA / CINP / IF / DRPE / PECB 1999. 80p

FRAGOSO, J. M. V. Large mammals and the dynamics of an Amazoniam rain forest. Gainesville, 1994. Dissertation (Ph.D) - University of Florida. 
FONSECA, G.A.B.; HERRMANN, G.; LEITE, Y.L.R.; MITTERMEIER, R.A.; RYLANDS, A.B.; PATTON, J.L. Lista anotada dos mamíferos do Brasil. Occasional Papers in Conservation Biology, v.4, p.1-38, 1996.

FONSECA, G.A.B.; RYLANDS, A.B.; COSTA, C.M.R.; MACHADO, R.B.; LEITE, Y. Livro vermelho de mamíferos brasileiros ameaçado de extinção. Belo Horizonte: Fundação Biodiversistas, 1994. 1v.

GALETTI, M. Indians within conservation units: Lessons from the Atlantic forest. Conservation Biology, v.15, n.3, p.798-799, 2001.

GONZÁLES-SOLIS, J.; GUIX, J.C.; MATEOS, E.; LLORENS, L. Density estimates, group size and habitat use of monkeys (mammals: cebidae). In: MATEOS, E.; GUIX. J.; SERRA, A.; PISCIOTTA, K (Ed.).Censuses of vertebrates in a Brazilian Atlantic Rainforest area: The Paranapiacaba fragment. Barcelona: Centre de recursos de biodiversitat animal, Universidade de Barcelona,2002. 217p.

HANAZAKI, N. Ecologia de caiçaras: uso de recursos e dieta. Campinas, 2001. 213p. Tese (Doutorado) - Instituto de Biologia, Universidade Estadual de Campinas.

IBAMA, SMA; NEPAM-UNICAMP. Diagnóstico ambiental participativo do Vale do Ribeira e litoral Sul de São Paulo: Subsídios para a discussão do plano de ação governamental para o desenvolvimento sustentável: São Paulo, Secretaria de Estado do Meio Ambiente, 1998. 1v. 
INSTITUTO FLORESTAL. Mosaico de fotografias aéreas da Mata Atlântica do Estado de São Paulo. São Paulo: Seção de Manejo e Inventário Florestal/ Divisão de Dasonomia, 2004.

JEROZOLIMSKI, A. Effects of subsistence hunting on the structure of mammal assemblages in neotropical forests. Norwich, 1998. Dissertation (Ph.D) - University of East Anglia.

JONHS, A.D.; SKORUPA, J.P. Reponses of rainforest primates to habitat disturbance: a review. International Journal of Primatology, v.8, n.2, p. 157-191, 1987.

LANE, F. A hunt for "Monos" (Brachyteles arachnoides) in the Foothills of the Serra de Paranapiacaba, São Paulo, Brazil. Articles: Neotropical Region, Primate Conservation n.11, p. 23-25, 1977.

LORIVAL, F.F.R.; FONSECA,G.A.B. Análise de sustentabilidade do modelo de caça tradicional no Pantanal da Nhecolândia, Corumbá, MS., In: PADUA-VALLADARES. C; BODMER, R.; CULLEN JUNIOR, L. (Ed.). Manejo e conservação da vida silvestre no brasil. Brasília: Sociedade Civil Mamirauá - CNPq. 1997, p.123-172.

MACE, G.M.; BALMFORD, A.; BOITANI, L.; COWLISHAW, G.; DOBSON, A.P.; FAITH， D.P.; GASTON， K.J.; HUMPHRIES， C.J.; VANE-WRIGHT， R.I.; WILLIAMS, P.H.; LAWTON, J.H.; MARGULES, C.R.; MAY, R.M.; NICHOLLS, A.O.; POSSINGHAM, H.P.; RAHBECK, C.; VAN JAARSVELD, A.S. It's time to work together and stop duplicating conservation efforts ... Nature, v. 405, n.6785, p. 393-393, 2000. 
MARTINS, E.S. A Caça de subsistência de extrativistas na amazônia: sustentabilidade, biodiversidade e extinção de espécies. Brasília, 1992. 116p. Dissertação (Mestrado) Universidade de Brasília.

MATEOS, E.; MAÑOSA, S. Memoria de resultados del segundo viaje de reconocimiento científico a regiones poco conocidas del Parque Estadual Intervales, Estado de São Paulo, Brasil. Dept. de Biologia Animal. Universitat Barcelona: Facultat de Biología, 1996. 57p.

MATEOS, E.; GUIX, J.; SERRA, A.; PISCIOTTA, K (Ed.).Censuses of vertebrates in a Brazilian Atlantic Rainforest area: The Paranapiacaba fragment. Barcelona: Centre de recursos de biodiversitat animal, Universidade de Barcelona, 2002. 217p.

MIRANDA, E. E. de; COUTINHO, A. C. (Coord.). Brasil Visto do Espaço. Campinas: Embrapa Monitoramento por Satélite, 2004. http://www.cdbrasil.cnpm.embrapa.br.

MITTERMEIER, R.A.; GIL,C.G.; MITTERMEIER,C.G. (Ed.). Megadiversity: Earth's Biologically Wealthiest Nations. 1997. México, Cemex. 1v.

MITTERMEIER, R.A.; MITTERMEIER, C.G.; MYERS, N.. HOTSPOSTS Earth's biologically richest and most endangered terrestrial ecoregions, Cemex, Conservation International, 2000. 430p.

MORAES, P.L.R. Caracterização morfológica de frutos, sementes e plântulas de espécies da família LAURACEAE, no Parque Estadual Carlos Botelho, São Paulo. Rio Claro, 1993. 190p. Dissertação (Mestrado) - Instituto de Biociências, Universidade Estadual de São Paulo. 
MYERS, N.; MITTERMEIER, R.A.; MITTERMEIER, C.G.; FONSECA, G.A.B.; KENT, J. Biodiversity hotspots for conservation priorities. Nature, v. 403, p. 853-858, 2000.

NATIONAL RESEARCH COUNCIL (NRC). Techniques for the study of primate populations ecology. Washington: National Academic Press, 1981. 1v.

NARANJO PIÑERA, E.J. Abundancia y uso de habitat de Tapir (Tapirus bairdii) en un bosque tropical húmedo de Costa Rica. Vida Silvestre Neotropical, v.4, n.1, p.20-31, 1995.

NAVARO, A.J.; REDFORD, K.H.; BODMER, R.E. Effect of hunting in source-sink systems in the neotropics. Conservation biology, v.14, n.3, p.713-721, 2000.

OLIVER, W.L.R.; SANTOS, I.B., 1991. Threatened endemic mammals of the Atlantic forest region of south-east Brazil. Jersey Wildlife Preservation Trust, Special Scien. Rep., 4:1-126. il.

PERES, C.A. Effects of hunting on western Amazonian primates communities. Biological Conservation, v.54, p.47-59, 1990.

PACCAGNELLA, S. G. Censo da população de monos (Brachyteles arachnoids) do Parque Estadual Carlos Botelho, Estado de São Paulo. A Primatologia no Brasil, v.3, p. 225-233, 1991. 
PARDINI, R. Pequenos mamíferos e a fragmentação da Mata Atlântica de Una, Sul da Bahia - Processos e Conservação. São Paulo, 2001. 147p. Tese (Doutorado) - Instituto de Biociências, Universidade de São Paulo.

PARDINI, R; DITT, E.H.; CULLEN JUNIOR, L. et al. Levantamento rápido de mamíferos terrestres de médio e grande porte. In: CULLEN JUNIOR, L.; RUDRAN, R.; PADUA-VALLADARES, C (Org.). Métodos de estudos em biologia da conservação e manejo da vida silvestre. Curitiba: Ed. da UFPR; Fundação O Boticário de Proteção à Natureza, 2003. cap.8, p.181-201.

REDFORD, K. H. The empty forest. Bioscience. v.42, p.421-422, 1992.

ROBINSON, J.G.; REDFORD, K.H. Subsistence and commercial uses of wildlife in Latin America. In: ROBINSON. J.G.; REDFORD, K.H (Ed.). Neotropical Wildlife Use and Conservation. Chicago: The University of Chicago Press, 1991, p.6-24.

ROLDÁN, A. I.; SIMONETTI, J.A. Plant-mammal interactions in tropical Bolivian forest with different hunting pressures. Conservation Biology, v.15, n.3, p. 617-623, 2001.

ROSSER, A.M.; MAINKA, S.A. Overexploitation and species extinctions. Conservation Biology, v.16, n.5, p. $584-586,2002$.

SANCHES, R.A. Caiçaras e a Estação Ecológica da Juréia - Itatins litoral sul - São Paulo. Uma abordagem etnográfica e ecológica para o estudo da relação Homem-Meio Ambiente. São Paulo, 1997. Dissertação (Mestrado) - Instituto de Biociências, Universidade de São Paulo. 1v. 
SCHUBART, H.O.R. Exame da situação atual da Hiléia Brasileira: Ecologia florestal, atividade humana recente e preservação da biota. In: Encontros Regionais sobre Conservação da Fauna e Recursos Faunísticos. 1976/1977. IBDF/FBCN. 1977, pp.1520.

SCOSS, L. M. Impacto das estradas sobre mamíferos terrestres: o caso do Parque Estadual do Rio Doce, Minas Gerais. Viçosa, 2002.86p. Dissertação (Mestrado) - Universidade Federal de Viçosa.

SILVA, C.R.. Riqueza de mamíferos não voadores em um mosaico formado por plantios de Eucalyptus saligna e remanescentes de floresta Atlântica no município de Pilar do Sul, SP. Piracicaba, 2001. 81p. Dissertação (Mestrado) - Escola Superior de Agricultura "Luiz de Queiroz", Universidade de São Paulo.

SISTEMA NACIONAL DE UNIDADES DE CONSERVAÇÃO - SNUC: lei nº 9.985, de 18 de julho de 2000. Brasília: MMA/SBF, 2000.32p.

VAN DYKE, F.G.; BROCKE, R. H.; SHAW, H.G; ACKERMAN, B.A.; HEMKER,T.H.; LINDZER, F.G. Reactions of mountain lions to logging and human activity. Journal of Wildlife Manage, v. 50, n.1, p.95-102. 1986.

VERDADE, L. The influence of hunting pressure on the social behavior of vertebrates. Revista Brasileira de Biologia, v.56, n.1, p. 1-13, 1996.

VOGLIOTTI, A.; DUARTE, J. M. B.; RODRIGUES, M. J. Aspectos etnozoológicos dos cervídeos da Mata Atlântica. Jaboticabal: Depto. de Zootecnia, Faculdade de Ciências Agrárias e Veterinárias. UNESP, 2002. 77p. (Relatório Final de Pesquisa FAPESP 1996/10246-0). 